\title{
The First 40 Million Years of Planktonic Foraminifera
}

\author{
Felix Gradstein ${ }^{1, *(\mathbb{D}}$, Anna Waskowska ${ }^{2} \mathbb{D}$ and Larisa Glinskikh ${ }^{3}$ \\ 1 Natural History Museum, University of Oslo, 0318 Oslo, Norway \\ 2 Faculty of Geology, Geophysics and Environmental Protection, AGH University of Sciences and Technology, \\ 30-059 Kraków, Poland; waskowsk@agh.edu.pl \\ 3 Trofimuk Institute of Petroleum Geology and Geophysics, Russian Academy of Sciences, \\ 630090 Novosibirsk, Russia; glor@mail.ru \\ * Correspondence: felix.gradstein@gmail.com
}

Citation: Gradstein, F.; Waskowska, A.; Glinskikh, L. The First 40 Million Years of Planktonic Foraminifera. Geosciences 2021, 11, 85. https:// doi.org/10.3390/geosciences11020085

Academic Editors: Lucilla Capotondi,

Maria Rose Petrizzo,

Angela Cloke-Hayes and

Jesus Martinez-Frias

Received: 10 December 2020

Accepted: 8 February 2021

Published: 13 February 2021

Publisher's Note: MDPI stays neutral with regard to jurisdictional claims in published maps and institutional affiliations.

Copyright: (c) 2021 by the authors. Licensee MDPI, Basel, Switzerland. This article is an open access article distributed under the terms and conditions of the Creative Commons Attribution (CC BY) license (https:// creativecommons.org/licenses/by/ $4.0 /)$.

\begin{abstract}
We provide a biochronology of Jurassic planktonic foramininfera, using first order linkage to ammonite and nannofossil stratigraphy and geochronology. This enigmatic and understudied group of microfossils occurred from middle Toarcian through Tithonian time, from 180 to 143 Ma; its origin is unknown. There are three genera: Globuligerina, Conoglobigerina and Petaloglobigerina. The genus Globuligerina, with a smooth to pustulose test surface texture appeared in Toarcian (late Early Jurassic) and Conoglobigerina, with a rough reticulate test surface texture in Oxfordian (early Late Jurassic) time. The genus Petaloglobigerina, having a petaloid last whorl with one or more claviform and twisted chambers evolved in early Kimmeridgian time from Globuligerina balakhmatovae. Biochronologic events for Jurassic planktonic foraminifera are most like First Common Appearance or Last Common Appearance events. The very first or very last appearance levels of taxa are not easily sampled and detected. We recognize stratigraphic events from eleven species across four postulated evolutionary lineages, calibrated to Geologic Time Scale 2020. A faunal change, which is not well documented led to the survival of only one taxon, most likely Gobuligerina oxfordiana in the Tithonian.
\end{abstract}

Keywords: planktonic foraminifera; Jurassic; chronostratigraphy; biochronology; evolution

\section{Introduction}

We provide a tentative biochronology of Jurassic planktonic foramininfera, using their taxonomy, stratigraphy, paleoecology and paleogeography with first order linkage to ammonite and nannofossil stratigraphy and geochronology. The study uses biochronostratigraphic information summarized in the section called 'Stratigraphic Inventory' on this enigmatic and understudied group of microorganisms. For one, studies on the earliest (Toarcian) record in this group are wanting, and there is no information on evolutionary transition in Tithonian time to Cretaceous planktonic foraminifera.

The summary below takes from our recent studies $[1,2]$. For details, including the formal taxonomy, the interested reader is referred to the monograph on this group of microfossils in [1,3]. The formal taxonomy also is provided in the Mikrotax internet site at http:/ / www.mikrotax.org. The Jurassic planktonic foraminifera were microperforate and probably all aragonitic in test composition, in equilibrium with Jurassic high-magnesium calcite seawater. The aragonitic test limits fossilization and may partially account for the scattered stratigraphic and paleogeographic distribution. We have not found evidence for dimorphism and asume reproduction was sexual as in recent planktonic foraminifera. The group occurred from middle Toarcian through Tithonian time, from $\sim 180$ to $143 \mathrm{Ma}$; its origin is unknown. The earliest record is from one locality in Turkey only, suggestive of the isolated population concept in evolution. The literature record since 1881 counts fewer than 100 publications [4].

Coiling mode, chamber configuration in the last whorl, test surface features and intraspecific variation in aperture shape are key taxonomic features; it precludes use of 
thin-sections for taxonomy. Some taxa have pore mounds and all but one may have a bulla. Jurassic test wall underwent evolutionary change from pustulose to reticulate. Creating a rougher wall surface texture is a biological measure to enhance drag and flotation, likely advantageous to Jurassic planktonic foraminifera.

There are three genera: Globuligerina, Conoglobigerina and Petaloglobigerina. Globuligerina, with a smooth to pustulose wall surface texture appeared in Toarcian (late Early Jurassic) and Conoglobigerina, with a rough reticulate wall surface texture in Oxfordian (early Late Jurassic) time. Petaloglobigerina, with a petaloid last whorl and one or more twisted and claviform chambers evolved in Kimmeridgian time from Globuligerina balakhmatovae. A dozen stratigraphic events are recognized across four evolutionary lineages, calibrated to Geologic Time Scale 2020 [5]. The Jurassic planktonic foraminifera preferred marine continental margin conditions along the margins of the Tethys Ocean.

This short study was invited for the Special Issue of Geosciences on "Application of Foraminifera in Biochronology", hence it is appropriate to briefly dwell on the historical background and meaning of biochronology and of paleontologic events. The latter is particularly relevant considering the paucity of Jurassic localities with common to frequent planktonic foraminifera as free specimens, and near absence of Jurassic outcrop or well sections with a continuous stratigraphic range of taxa over several zones.

\section{Principles of Biochronology}

Biostratigraphic correlation is not necessarily time correlation. It may approximate time-correlation, or it may be the identification of the same biofacies and potentially be diachronous, because comparable fossil record in samples some distance apart, does not imply synchronicity of deposition.

The above conservative statement comes from the International Stratigraphic Guide [6]. The Guide recognizes (and sparsely defines) units and principles of biostratigraphy, but does not recognize and define biochronology. The most likely reason is that the latter is a predictive interpretation, and not an observation and description of fossil correlation. In its formal stratigraphic presentation the Guide has no place for biochronology, since the latter resolutely bypasses zones, stages and chronostratigraphy on its way to geochronology.

Biochronology avoids the classical concept of zones (and stages), in favour of 'the organisation of geologic time according to the irreversible process of evolution in the organic continuum' [7]. The authors lament that the essential desire to extend correlation in time, mistakenly is an activity in stratigraphy, whereas it properly is an exercise in geochronology: "Biochronology attempts to rank, order and scale fossil events and fossil ranges in linear time, and scale regional stratigraphies with isochrons".

Despite not being honoured by the International Stratigraphic Guide, biochronology is really what a great many paleontologists and stratigraphers are after. Many studies aim to generate an optimum network of fossil correlations, thought to embody a reliable and high-resolution isochronous time (lines) framework. Linking such a network with magnetochrons, stable and unstable isotope determinations, and cyclothems, albeit in danger of inviting circular reasoning, creates a geochronologic correlation framework.

\section{Paleontologic Events}

The key to biochronology and its building blocks are fossil events. A fossil or paleontological event is the presence of a taxon in its time context, derived from its position in a rock sequence. Most commonly used are First Appearance and Last Appearance Datum's (FAD and LAD). Since the first or last appearance datums may be difficult to recognize or distinguish where specimen numbers dwindle or get obscured by 'noise' (like reworking of fossil tests), it can be advantageous to substitute with first and last consistent (or common) appearances. A first or last appearance datum is consistent when such stratigraphic range endpoints are part of an observed continuous stratigraphic range (Figure 1). 


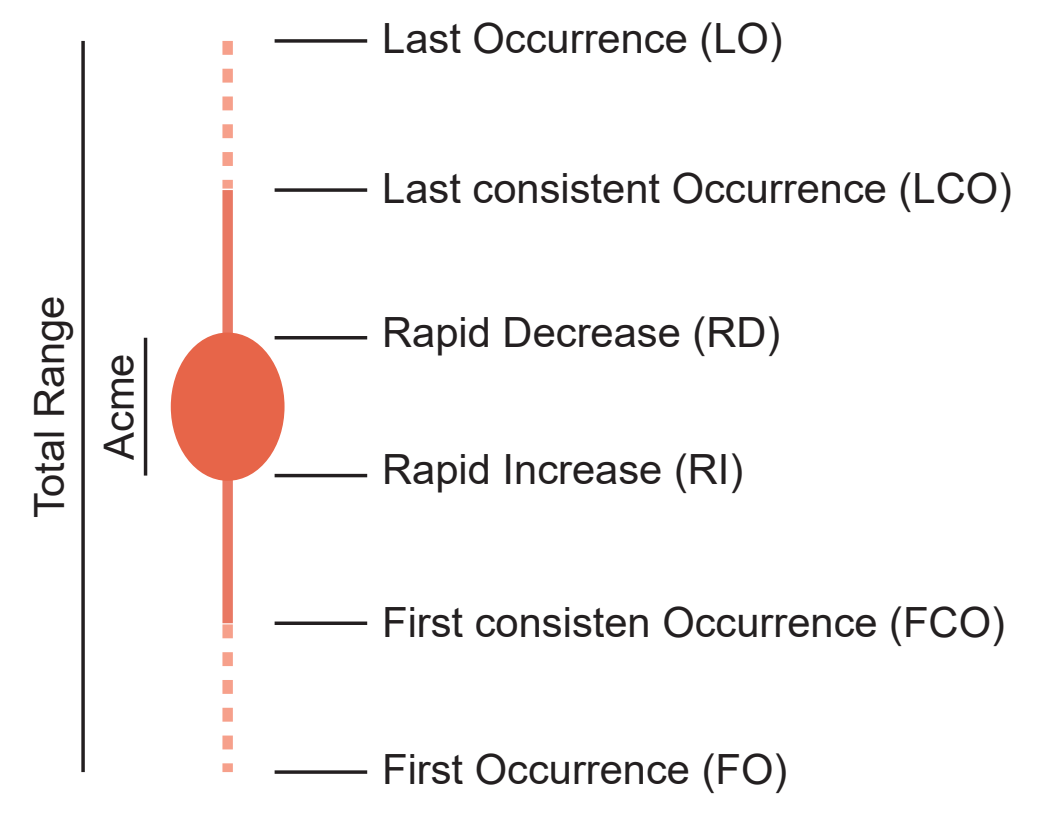

Figure 1. Terminology of biostratigraphic events along the total stratigraphic range of a single taxon. The first and last consistent occurrence may coincide with the first and last common occurrence; the rapid increase and rapid decrease encapsulate the acme of the taxon. Instead of First or Last Occurrence, First or Last Appearance is frequently used. The former is a chronostratigraphic term, and the latter a geochronologic one.

If the fossil record encountered in stratigraphic sections that we want to correlate and calibrate in time would be ubiquitous and perfect, i.e., if only time would control the appearance, range and disappearance of taxa, then biostratigraphy would be a straightforward exercise. The science of biochronology, as developed for the evolutionary first and last occurrence datums of ocean plankton, in conjunction with geomagnetic reversals in Deep Sea Drilling Sites, would be a matter of systematic book keeping on a worldwide scale, only constrained by taxonomic deliberations. Unfortunately, the paleontological record is highly imperfect, and its noise may call for more intricate, or even murky biostratigraphic decision making (for example when absence of occurrence is an argument) that detracts from the validity of a potential biochronologic framework.

Factors bearing on the quality of the fossil record are in Figure 2. Together, these uncertainty factors are as follows:

(1) Quality and quantity of sampling

(2) Specimen frequency of fossil taxa

(3) Confidence of taxonomic identification

(4) Influence of environmental change on the stratigraphic range of taxa

(5) Differential rate of taxon evolution in different parts of the world

(6) Time lag in migration of taxa, where correlation is over large distances, or across major environmental barriers. 

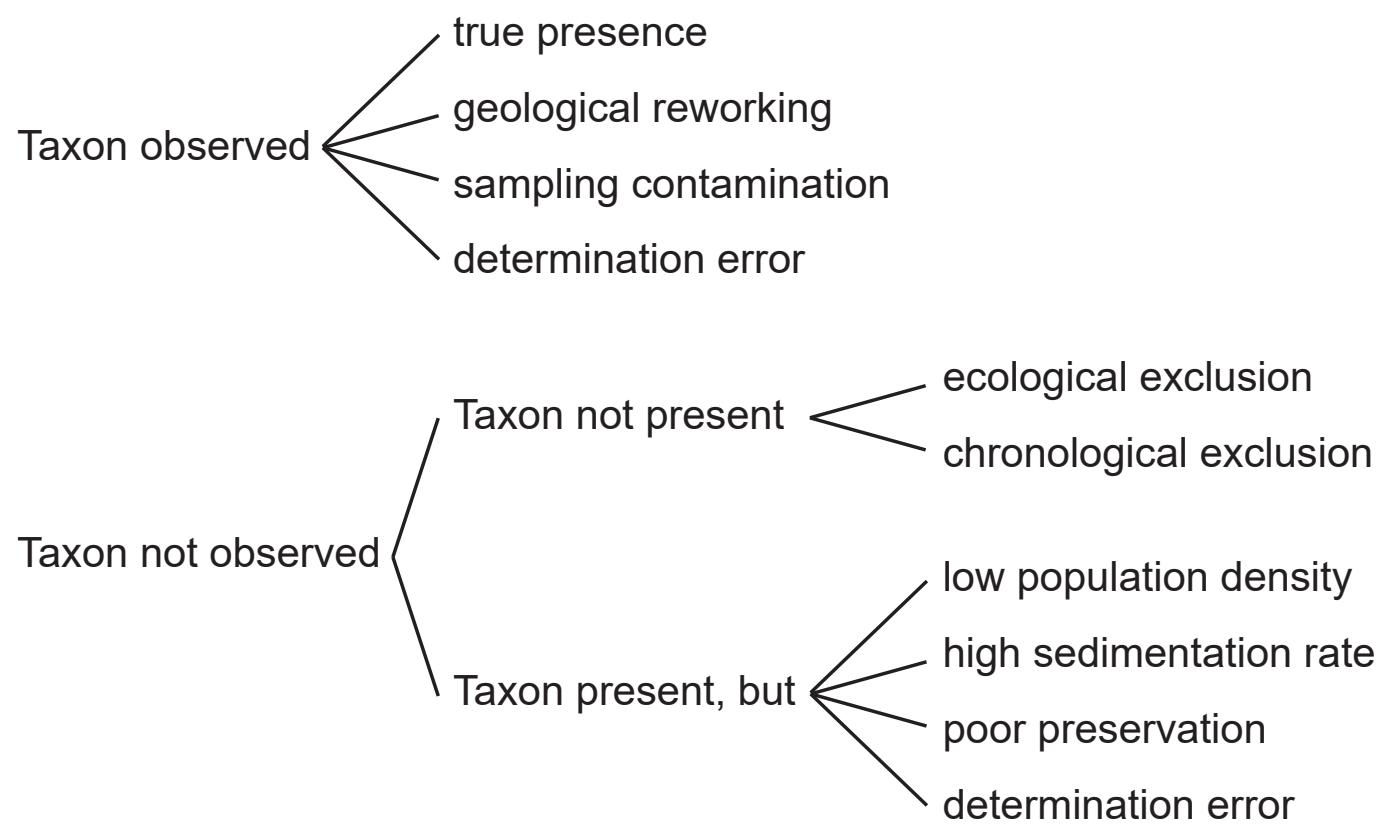

Figure 2. Sampling factors bearing on the quality of the paleontologic event record. With Jurassic planktonic foraminifera the state of preservation, either aragonitic (which is the original composition of the test) or calcitic plays a role, and so does the rate of sedimentation. For details, see text.

A more extensive description of these factors is in Gradstein et al. (1985). If significant diachroneity is observed for bioevents, e.g., by plotting them against magnetochrons or time calibrated stable isotope spikes in two or more sections, than a numerical method or graphic illustration should be devised to quantify the error bar on bioevent correlations. As a matter of routine latitudinal or environmental shifts in event calibrations should be taken into account.

An important lesson from these factors bearing on the quality of the fossil record is that biochronologic events for Jurassic planktonic foraminifera are most like First Common Appearance or Last Common Appearance events, or even the acme. The very first or very last appearance levels are not easily sampled sampled and detected.

\section{Material and Methods}

The Polish, Dagestan and Portuguese outcrop sections and offshore eastern Canada well sections were described with great stratigraphic detail and with complete geographic notations in [1].

In addition to standard Leica (M205C with PLANAPO $1.0 \times$ and $1.6 \times$ objectives and Nikon stereo microscopes, good use was made for wall surface texture determination of the Leica DM 750M biological microscope with polarizer/analyser and Epi 10×/0.25 and N Plan L 20× / 0.35 and Plan L50 × /0.50 objectives. Both objectives have long distances between objective and specimen and allow optimum incident light illumination. Digital optical images were acquired efficiently with a Deltapix M12ZS digital microscope with $1.25,2.5$ and 4.16 objectives and Insight stacking software. SEM images were obtained with a QUANTA 200 FEG scanning microscope at the Laboratory of Phase, Structural, Textural and Geochemical Analyses of the Faculty Geology, Geophysics and Environmental Protection at AGH (Krakow, Poland).

\section{Stratigraphic Inventory}

Below we describe in stratigraphic order, from Toarcian through Berriasian-early Valanginian our sample material with planktonic foraminifera as free tests from washed sample residues. The listing of these 25 localities worldwide also includes critical literature references with planktonic assemblages from which we do not have specimens or sample 
material (indicated with a small $x$ ). Figure 3, in an approximate manner shows the majority of localities from which Jurassic planktonic foraminifera are known [3] including the key ones on which the current analysis is based. The zonal and age assignments, as derived from ammonite or nannofossil zonations follow the chronostratigraphic subdivisions of the Jurassic and earliest Cretaceous stages in [8-10]. Note that the early, middle and late subdivision of stages is not formalized and open to change.

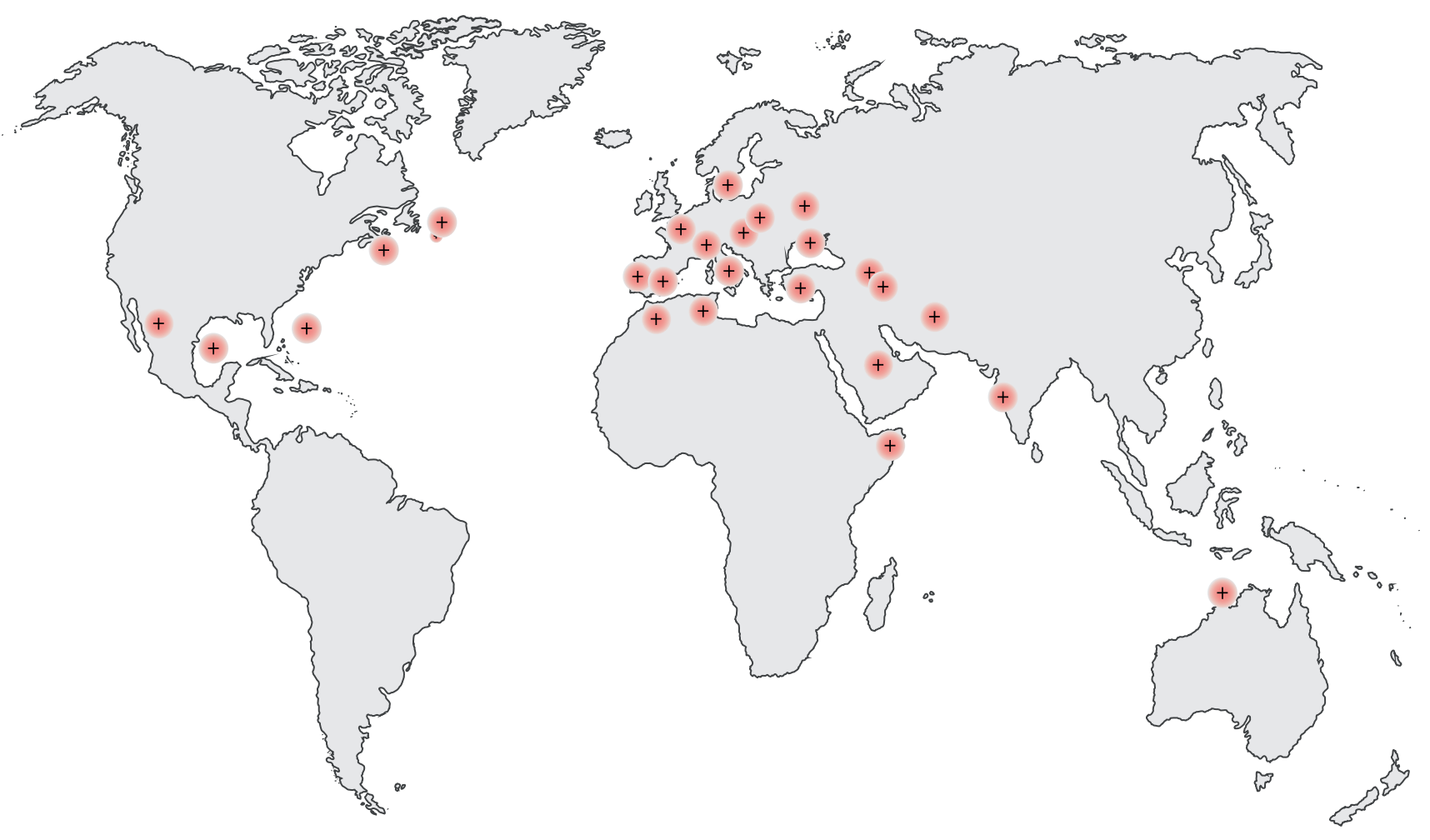

Figure 3. Approximate occurrence of Jurassic planktonic foraminifera in the Tethyan—sub Tethyan marine belt; see [1,3] for details.

Middle Toarcian, SW Turkey (x)

Bifrons-Variabilis Zones, thin-sections, Globuligerina spp.; tests on average $150 \mu \mathrm{m}$ [11]. Early Aalenian, SW Turkey

Opalinum Zone, thin-sections, Globuligerina spp., (thick walled), tests on average $250 \mu \mathrm{m}$ [11].

Early Bajocian, Morocco (RIF) (x)

Sauzi Zone, Globuligerina spp., tests on average $280-300 \mu \mathrm{m}$, maximally $340 \mu \mathrm{m}$ [12]

Early Bajocian, NW Australia (x)

Study and locality: Small clay samples from marine dredges acquired along the NW Australian Continental Margin, facing the Argo Abyssal Plain of Tethys contain about 75+ fragile and small, aragonitic planktonic foraminifera.

Age: Early Bajocian, using nannofossils and dinoflagellates.

Microfossil assemblage: Globuligerina oxfordiana, G.bathoniana and a species that maybe endemic to this region. The assemblage needs comparative study.

Reference: Apthorpe (2020) [13].

Middle Bajocian, Hungary (x)

Study and locality: Hard "Ammonitico Rosso" limestone of Som Hill, Bakony Mountains yielded a diversified and rich planktonic foraminifera assemblage, using weak acidisation to disengage the tests from the limestone matrix. The acidisation does not preserve wall surface textures of the test, necessary to differentiate genera. 
Zones and age: Humphriesianum and Niortense Zones, middle Bajocian.

Assemblage: The planktonic assemblage is diverse and dominated by large specimens, often reaching $400 \mu \mathrm{m}$ in diameter, including Globuligerina aff. dagestanica, Globuligerina oxfordiana (medium and large forms), Globuligerina aff. bathoniana (large form), and Globuligerina avariformis.

Reference: Wernli and Görög (1999) [14].

Middle Bajocian, France (x)

Study and locality: Find of Jurassic planktonic foraminifera in the type section of the Bajocian Stage, France.

Zone: Humphriesianum Zone, middle Bajocian.

Assemblage: Poorly preserved Globuligerina oxfordiana in a biomicrite with ferriginous oolites, attesting to the shallow marine nature of the sediment.

Reference: Bignot and Janin (1984) [15].

Late Bajocian, Azerbijan (x)

In 1984 Kasimova and Aliyeva [16] briefly described Conoglobigerina avariformis Kasimova from the Bajocian of Azerbaijan. The holotype drawings provide no wall sculpture information, but a metatype specimen illustrated in [17] has short pseudomurical ridges.

Late Bajocian-Early Bathonian, Dagestan (Russia)

Study and locality: In 1961, Morozova and Moskalenko [18] described for the first time a rich Jurassic 'Globigerina' biofacies, with abundant free specimens of several taxa. The assemblage occurs in fine grained, bathyal shales near the villages of Gunib and Chokh, Central Dagestan, NE Caucasus. The Gunib section has geographic coordinates $42^{\circ} 23^{\prime} 16^{\prime \prime} \mathrm{N}, 46^{\circ} 57^{\prime} 40^{\prime \prime} \mathrm{E}$, and the Chock section $42^{\circ} 19^{\prime} 18^{\prime \prime} \mathrm{N}, 47^{\circ} 1^{\prime} 57^{\prime \prime} \mathrm{E}$.

Zones and Age: Parkinsonii and Zigzag Zones, late Bajocian-early Bathonian.

Assemblage: Globuligerina dagestanica, Globuligerina balakhmatovae and Globuligerina oxfordiana. The planktonic assemblage is associated with epistominids and discorbids.

Through the courtesy and cooperation of Temirbekova Umuhayabat Temirbekovna (Makhachkala, Dagestan, Russia) we obtained Jurassic planktonic specimens from the type sections near Gunib and Chokh in Central Dagestan. This allowed us to study topotype specimens. Through the courtesy of Ludmila Kopaevich we also obtained micropaleontology slides with planktonic foraminifera of the Gunib and Chokh sections from the Gorbachik collection in Moscow.

References: Morozova and Moskalenko (1961) [18]; Gradstein et al. (2017) [1].

Late Bajocian-Early Bathonian, Dagestan (Russia)

Study and locality: Co-author L.G. participated in 2015 in a field trip to a nearby and stratigraphically identical section $\left(42^{\circ} 9^{\prime} 23^{\prime \prime} \mathrm{N}, 47^{\circ} 7^{\prime} 60^{\prime \prime} \mathrm{E}\right)$ to Gunib and Chokh. This means that the Jurassic planktonic foraminifera in it are essentially topotypes of those described first by Morozova and Moskalenko [18]. The stratigraphic levels in this new section XУРУКРA (Khouroukra) were studied and sampled together with specialists in ammonite and belemnites. The studied part of the Khouroukra section includes the lower and middle subformation of the Tsudakhar Formation.

The lower subformation shows interbedded light gray siltstones and sandstones. The middle subformation consists of a dark gray claystones, with interbeds of siltstones, rare sandstones, with siderite concretions. There are rare and thin $(0.10-0.15 \mathrm{~m})$ interbeds of calcareous rocks.

Zones and age: Parkinsonii and Zigzag Zones, late Bajocian-early Bathonian.

Assemblage: Gastropodes, ostracodes and a relatively rich and diversified benthonic foraminifera assemblage with Hyperammina, Trochammina, Reophax, Ophthalmidium, Ichthyolaria, Dentalina, Lenticulina, Oberhauserella, Epistomina and Discorbis (D. paraspis), together with planktonic foraminifera. The latter are well preserved and common and include Globuligerina dagestanica, Globuligerina oxfordiana, Globuligerina glinskikhae and Globuligerina balakhmatovae.

References: Gradstein et al. (2017) [1]; Gradstein and Waskowska (2021) [2].

Bajocian-Bathonian-Callovian, Grand Banks, offshore eastern Canada 
Study and stratigraphy: From 1970 until 1995 the senior author F.G. was professionally involved with the biostratigraphy of the sedimentary wedge along the continental margin of eastern Canada.

Zones and age: Garantella-, Globuligerina bathoniana- and Reinholdella crebra var. Zones, Bajocian through Callovian.

Microfossil assemblages: In side-wall-cores (swc) and cuttings (cts) samples between 10600 and 6230 feet in the Eider M-75 well Globuligerina bathoniana and Globuligerina oxfordiana occur in abundance, and Globuligerina balakhmatovae is common. Preservation of the calcite tests is excellent. The same three species also occur in the same stratigraphic interval in the Murre G-67 and Cormorant N-83 wells. In swc's at 5000 and 5350 feet in the Bittern M-62 well, assigned to the Reinholdella crebra var Zone (Callovian) Globuligerina tojeiraensis occurs with few specimens together with a small and compact globigerinid form tentatively determined as Conoglobigerina grigelisi. Deeper in the same well assigned to the Globuligerina bathoniana Zone (Bathonian) occur Globuligerina balakhmatovae and Globuligerina bathoniana.

References: Gradstein (1976) [19], Stam (1986) [20], Gradstein et al. (2017) [1].

Middle Bathonian, Portugal

Rare specimens of Globuligerina bathoniana occur in the shallow marine sedimens of middle Bathonian age in the Brenha Road section, Mondego area, Portugal [20].

Middle Bathonian, Poland

Study and locality: In 1969, Pazdrowa published 'Bathonian Globigerina from Poland' [21]. The taxon Globigerina bathoniana was described with about 150 well-preserved specimens from the ore-bearing clays of Ogrodzieniec, Zawiercie County, Southern Poland at $50^{\circ} 27^{\prime} \mathrm{N}$ and $19^{\circ} 31^{\prime}$ E. Author F.G. received from Pazdrowa a foraminiferal assemblage from Ogrodzieniec, including the globigerinid taxon. Later, he undertook self micropaleontological sampling of the strata in the Ogrodzieniec claypit; these samples were used in the Ph.D. study by Stam [20]. Now, the Ogrodzieniec quarry has been partly filled in and made inaccessible (but see below).

Zone and age: Morrisi Zone, middle Bathonian.

Assemblage: The local foraminiferal assemblage is diverse, and from the list of taxa received from Olga Pazdrowa includes: Garantella ornata, Reinholdella crebra, Epistomina regularis, E. costifera, E. nuda, Paleomiliolina czestochowiensis, Ophtalmidium agglutinans, O. carinatum, Paalzowella pazdroae, Spirillina radiata and Conorboides paulus. According to [22] the Jurassic planktonic foraminifera lived in a shallow marine basin with siliciclastic sedimentation. We interpret this paleo environment as probably deep neritic, using the evidence from epistominids with Jurassic planktonic foraminifera from other basins (Stam, 1986).

References: Pazdrowa (1969) [21]; Stam (1986) [20]; Gradstein et al. (2017) [1].

Middle Bathonian, Poland

Study and locality: After the Ogrodzienie quarry became non-existent (see above), co-author AW undertook fieldwork and sampling of the same Morissi ammonite Zone in the Gnaszyn iron ore quarry in the southern part of Kraków-Silesia. The Gnaszyn (Gnaszyńscy) quarry (coordinates: $50^{\circ} 48^{\prime} 11.4^{\prime \prime} \mathrm{N}, 19^{\circ} 02^{\prime} 31.9^{\prime \prime} \mathrm{E}$ ) is located in the S.W. Czestochowa city area of the Gnaszyn district. The $25 \mathrm{~m}$ thick section of dark shales represents the higher part of the Czestochowa ore-bearing clay formation being locally $140 \mathrm{~m}$ thick. The monotonous, strongly bioturbated black or dark greyish siltstones and claystones are rich in bioclasts, occasionally with different amount of sandy admixture. It contains seven levels of sphaerosideritic concentrations (N-T horizons).

Zone and age: Morrisi Zone-middle Bathonian.

Fossil assemblage: There is a diverse and rich fossil fauna with ammonites, belemnites, bivalves, scaphopods, gastropods, foraminifers, echinoderms and shark teeths, as well as trace fossils, calcareous nannoplankton, pollen, sphoromorphs, dinoflagellates and driftwoods. Benthic foraminifera include are dominated by Ceratobuliminidae and Vaginulinidae, and smaller numbers of agglutinated taxa. 
The Jurassic planktonic foraminifera bearing GN-6 sample was taken in the lower part of the Gnaszyn section. This is a grey and slightly sandy claystone with numerous bioclasts, mainly of mollusks shells. The sample is rich in very well preserved, aragonitic planktonic foraminifera with Globuligerina oxfordiana and fewer Globuligerina bathoniana, Globuligerina glinskhikae and Globuligerina waskowskae.

References: Smoleń (2012) [22]; Gedl et al. (2012) [23]; Gradstein et al. (2017) [1]; Gradstein \& Waskowska (2021) [2].

Middle Callovian, Portugal

Study and locality: Along the Mareta Beach section in southern Portugal, thick and well bedded calcareous shales crop out, locally with thin sand layers with ripple marks, load and flute casts, and upwards in the beach section with more marls and limestones. The shales and marls have common Bositria.

Zone and Age: Bordalo da Rocha (1976) [24] assigned a late Bajocian through Callovian age to the lithological unit, using a detailed ammonite zonation.

Micropaleontologic assemblage: Middle Jurassic foraminiferal paleoecology and Jurassic planktonic foraminifera in the Mareta Beach section were investigated by Stam (1986). In sample 31 (Coronatum Zone, middle Callovian), the author recognized rare Globuligerina bathoniana. The neritic setting of the Callovian strata, with few epistominids, does not lend itself to find Jurassic planktonic foraminifera in abundance.

References: Bordalo da Rocha (1976) [24]; Stam (1986) [20]; Gradstein et al. (2017) [1].

Early Oxfordian, NW France

Study and locality: In 1966, Bignot and Guyader [25] discovered several dozen small specimens of Globuligerina oxfordiana (Grigelis) in the clays of Villers, Le Havre, Normandy, Northwest France.

Zone, stage and microfossil assemblage: The level is lower Oxfordian, Mariae Zone, about $6 \mathrm{~m}$ below the Cordatum zone with ferruginous oolites. Jurassic planktonic foraminifera are from a low energy, shallow marine embayment, connected to open sea. Using the paleo waterdepth model of Stam (1986) the species lived in a shallow marine environment, not exceeding $150 \mathrm{~m}$ in paleo waterdepth (Samson et al., 1992) [26]. G. Bignot kindly donated Globuligerina oxfordiana specimens to Gradstein for comparison to Grand Banks specimens.

References: Bignot and Guyader (1966) [25]; Stam (1986) [20]; Gradstein et al. (2017) [1]; Gradstein and Waskowska (2021) [2].

Middle Oxfordian, Switzerland

Study: In April 2016, author Gradstein visited the Natural History Museum in Basel, Switzerland to study type slides listed to contain Globigerina helvetojurassica Haeusler, and also sample the nearby Eisengraben Section to obtain fresh microfossil material containing this species. The museum type slides did not contain suitably preserved specimens of this taxon, and are unrecognizable, but topotypes of this taxon were successfully sampled, under the expert guidance of Etter and Knappertsbusch.

Locality: The Eisengraben Section, ca $35 \mathrm{~km} \mathrm{N-W}$ of Zuerich in Canton Aargau, Switzerland is the type section of the Birmenstorfer Schichten, Tranversarium Zone, middle Oxfordian. The section has coordinates $651,600 / 264,070$ on Schweizerische Landeskarte 1:25,000, Blatt 1069, Frick (reference Figure 4 in Oesterle, 1968 [27]).

Zone-stage: Transversarium Zone, middle Oxfordian.

Microfossil assemblage: Directly below level 4 in the Eisengraben Section, samples with common and well-preserved specimens were obtained that we consider to be topotypes of Conoglobigerina helvetojurassica (Haeusler). Also, rare specimens were obtained of small sized Globuligerina bathoniana and G.oxfordiana. Level 4 top has many agglutinated taxa, but hardly any planktonic specimens. Sample 4 mid, at the level of Stam's sample with 'helvetojurassica' has best preserved specimens, and also includes well-preserved benthics belonging in Bigenerina, Textularia, Ophthalmidium, Ammodiscus, Glomospira, Trochammina, Haplophragmoides, Dentalina, Nodosaria, Lenticulina plus some indeterminate taxa. Micro gastropods also occur. Small limonitic concretions are common; small glauconite lumps 
also occur, testifying to a likely neritic mode of deposition. There are no epistominid benthic taxa.

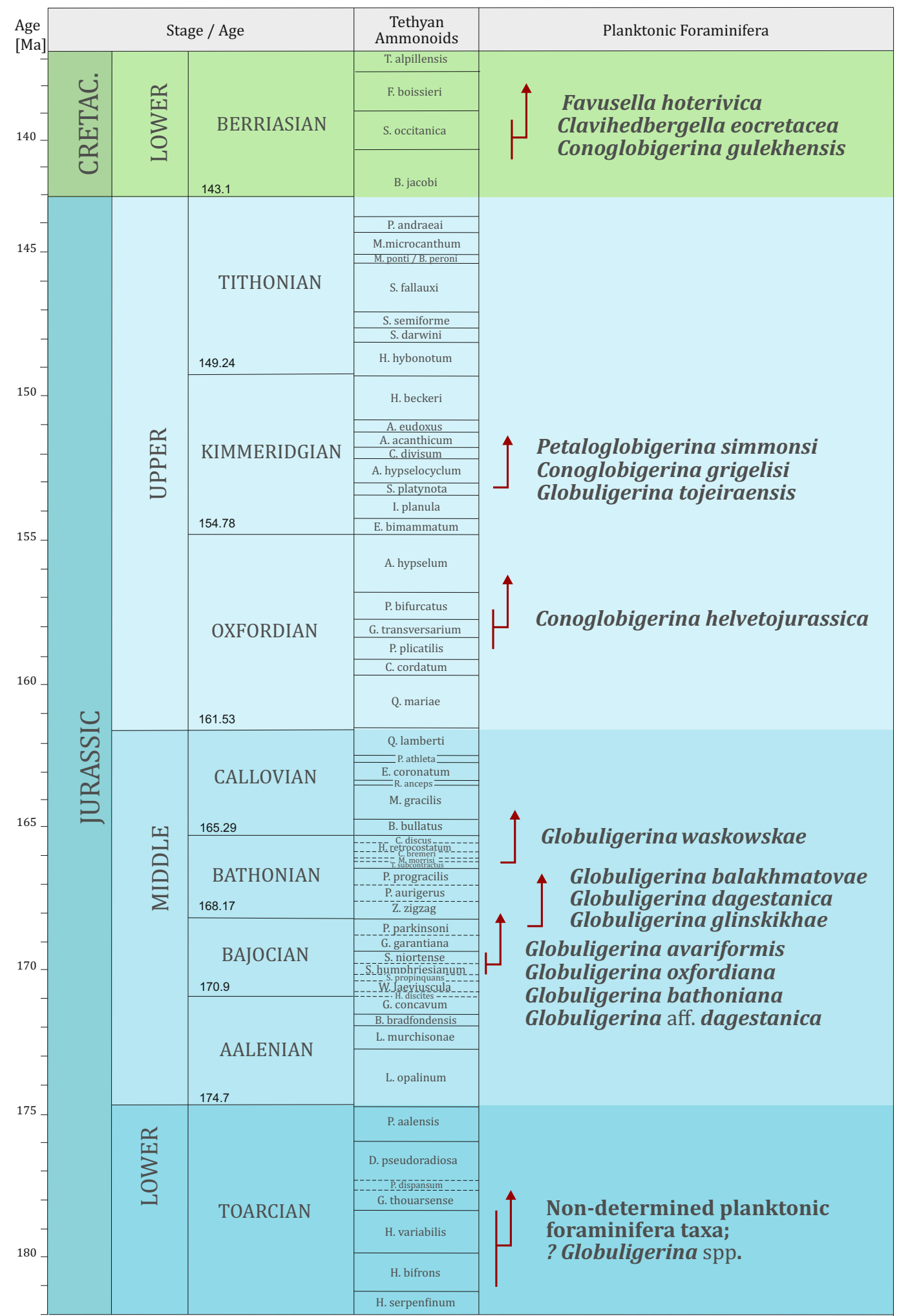

Figure 4. First Appearance Datum (FAD) of species of Jurassic planktonic foraminifera, calibrated to ammonite and nannofossil stratigraphy, as outlined in the text. Event level uncertainty beyond the duration of the ammonite zone(s) in which FAD's were determined is not taken into account in this study. 
Micropaleontology slides of Oesterle (1968) [27] in the Basel Museum from the Birmenstorfer type section contain 50+ of many more (often broken) specimens which we studied that show the same test moulds of crystallized carbonate fragments. The peculiar preservation is the result of a rigorous processing technique (likely a form of acetolysis). At least five morphotypes may be distinguished, which, despite poor preservation, can easily be assigned to the species Globuligerina aff. oxfordiana, Globuligerina aff. bathoniana, Globuligerina aff. jurassica (with an elongated, high spired and irregularly trochospiral test), Globuligerina aff. balakhmatovae, Globuligerina aff. tojeiraensis (with slightly elongated last chamber) and Conoglobigerina aff. grigelisi. However, the latter might be Globuligerina aff. avariformis, since we cannot determine wall texture. For sampling details and plates with SEM illustrations of all planktonic taxa, including the topotypes of Conoglobigerina helvetojurassica see [28].

References Oesterle (1968) [27]; Gradstein et al. (2017) [1].

Oxfordian, Lithuania and Russia

Study and localities: A brief description is provided of the type localities of Globuligerina oxfordiana based on the author's (A. Grigelis) notes made on boreholes during his field work in Lithuania in 1956, and in the Nikitino region of central Russia in 1977. Microfaunal remnants were picked by the author after standard sediment disintegration and hand-sieving procedure. The shallow burial at the Oxfordian localities accounts for excellent preservation of the Globuligerina oxfordiana taxon.

Geologically, the Lithuanian area belongs to the Precambrian East European Craton. Relatively thin Mesozoic sedimentary strata underly Quaternary surface deposits. Marine Jurassic is distributed in the western-south-western part of Lithuania, with thickness changing from less than $30 \mathrm{~m}$ in the northwest to $250 \mathrm{~m}$ in the southwest, against the border with Poland.

Microfossil assemblage: Holo- and paratypes of Globuligerina oxfordiana come from dark claystone and dark siltstone in borehole Jotija (Jotija village), Sakiai District, Lithuania at $143 \mathrm{~m}$ below surface in sample 10, lower Oxfordian (type specimens are provided by A. Grigelis on Plate 12 in [1]). In the original description it is not indicated on which evidence geological age is assigned, but the foraminiferal assemblage contains Spirophthalmidium birmenstorfense, Lenticulina brueckmanni, L. comptala, Vaginulina flabellata, Trocholina transversarii, Epistomina volgensis, E. brueckmanni and Epistominoides sp. GPS coordinates of the borehole site are $55^{\circ} 02^{\prime} 17^{\prime \prime} \mathrm{N}, 23^{\circ} 11^{\prime} 42^{\prime \prime} \mathrm{E}$.

Well-preserved specimens of Globuligerina oxfordiana also occur in dark, micaceous silty clay in the interval of 55-66 m in borehole Lyduvenai, Raseiniai District, Lithuania. GPS coordinates of this site are $55^{\circ} 30^{\prime} 29^{\prime \prime} \mathrm{N}, 23^{\circ} 04^{\prime} 59^{\prime \prime} \mathrm{E}$. The type level contains the ammonite Cardioceras tenuicostatum Nikitin (early Oxfordian) and the foraminifera Epistomina volgensis, Epistomina intermedia and Lenticulina brueckmanni.

In Central Russia, well preserved specimens of this taxon (as assigned by Grigelis) also occur in sample 801 in the Shatriche-2 outcrop at the Nikitino settlement on the river Oka, Ryazan District. The actual outcrop is on high right bank of River Oka, ca $2.5 \mathrm{~km}$ below the confluence with River Pronya, at outskirt of village Shatriche, in a river washout called "Durnyanki". The sampled sediments are assigned to the middle to late Oxfordian, but no specific fossil information is provided. Type specimens of this species provided by A.Grigelis on Plate 12 in [1].

References: Grigelis (1958) [29]; Gradstein et al. (2017) [1].

Oxfordian, Poland

Study and locality: A prominent Globuligerina limestone in Poland occurs in the Pieniny Klippen Belt (PKB). Co-author A.W. obtained hard limestone samples of Oxfordian age from the isolated Obłazowa Klippe block in Nowa Biała village (coordinates: $49^{\circ} 25^{\prime} 42,4^{\prime \prime} \mathrm{N}, 20^{\circ} 07^{\prime} 35,5^{\prime \prime} \mathrm{E}$ ).

Micropaleontologic assemblage: Thin-sections show that Globuligerina oxfordiana is abundant and rock-forming, and Globuligerina bathoniana is rare. 
References: Birkenmajer (1977, 1986) [30,31]; Wierzbowski et al. (1999) [32]; Gradstein et al. (2017) [1].

\section{Oxfordian, Blake Bahama Basin, North Atlantic Ocean}

Study: Deep Sea Drilling Site (DSDP) 534, on the landward side of marine Jurassic Magnetic Quiet Zone (JQZ), in the Blake-Bahama Basin, established a Middle Jurassic (Bathonian-Callovian) age for the opening of the N. Atlantic Ocean.

Microfossil assemblage: The site cored abyssal ( $>2.7 \mathrm{~km}$ paleo waterdepth) Jurassic sediments with well preserved and common benthic foraminifera, nannofossils, radiolarians and dinoflagellates. It failed to find in situ Jurassic planktonic foraminifera. Rare, small and poorly preserved Globuligerina aff. oxfordiana specimens in Core 110 of Oxfordian age, are interpreted as transported with gravity flows from shallower strata. DSDP Leg 11, Site 105, drilled in this region in 1972, in this region yielded similar observation.

References: Gradstein (1983) [33]; Luterbacher (1972) [34].

\section{Early Kimmeridgian, Portugal}

Study: Between 1978 and 2016, author FMG with colleagues and students undertook several stratigraphic surveys and sampling in road outcrops, mountain sections and beach cliffs with Jurassic marine strata in Central and South Portugal. The research was part of a stratigraphic study of the Grand Banks of Newfoundland and its conjugate basin. The Grand Banks and Portugese Jurassic basins were conjugate, prior to mid-Cretaceous oceanisation of this segment of the North Atlantic.

Over the years, several stratigraphers and paleontologists generously provided guidance in the field, and assisted with analysis of ammonites and microfossils collected. These specialists included: Mouterde and Ruget Perrot (University of Lyon, Lyon, France), Ramalho (Geological Survey, Lisbon, Portugal), da Rocha (New University of Lisbon, Lisbon, Portugal), Wilson (The Open University, UK), Poulton (GSC, Calgary, AB, Canada), Gale and Turner (University of Portsmouth, Portsmouth, UK) and Watkins (Department of Earth and Atmospheric Sciences, Nebraska University, Lincoln, NE, USA).

Locality: Several sections in the marly Tojeira Formation, over $70 \mathrm{~m}$ thick, in hills near the hamlet of Ramada and the villages of Pereiro, Tojeira an Vila Verde dos Francos, Montejunto area, Estramadura, west central Portugal. Details are in [1].

Zone-stage: Platynota-Hypselocyclum Zones, early Kimmeridgian

Microfossil assemblage: The Tojeira Formation is rich in fairly well preserved planktonic foraminifera and a very large collection of specimens was made, with seven taxa described. The taxa include Globuligerina oxfordiana, Globuligerina bathoniana, Globuligerina tojeiraensis, Globuligerina balakhmatovae, Petaloglobigerina simmonsi, Conoglobigerina grigelisi and Conoglobigerina helvetojurassica. Planktonic foraminiferal tests are calcitic, nor aragonitic. The Portugese Jurassic planktonic foraminifera occur together with a rich epistominid assemblage, also found in Grand Banks sections with Pseudolamarckina rjasanensis, Epistomina mosquensis and Epistomina uhligi. Agglutinated foraminiferal taxa and micro-gastropods are common; the calcareous benthic foraminifera Discorbis paraspis and Discorbis scutiliformis are rare. The benthic foraminiferal assemblage is only known from deeper neritic and bathyal settings [20].

References: Stam (1986) [20]; Agterberg et al. (1989) [35]; Gradstein et al. (2017) [1]; Turner et al. (2017) [36]; Gradstein and Waskowska (2021) [2]; Görög and Wernli (2013) [37].

Middle Kimmeridgian, Portugal

Study and locality: In 1978, as part of the extensive Tojeira Formation sampling (see above), Rogerio Bordalo da Rocha (Lisbon) kindly guided author F.G. and students to two dark shales outcrops, one along the road just outside Villa Verde dos Francos and another one outside Pereiro, both in the Montejunto area. The fossiliferous shales with ammonites and Bositria are of the Abadia Formation, that overly the Tojeira Formation and underly thick-bedded conglomeratic sands. In the Montejunto area, the Abadia Formation, with shales, sands, conglomerates and olistolithic limestone blocks reach a thickness of over $1 \mathrm{~km}$.

Zone and age: Middle Kimmeridgian, according ammonite studies of the Portugese Geological Survey. 
Micropaleontologic assemblage: Our samples 4/1 and 25/1 have large size benthic foraminifera with Epistomina stellicostata, E.volgensis and E.uhligi. The first two taxa do not occur in the underlying Tojeira Formation, and have their first, regional stratigraphic occurrence in these two samples. In correlation with eastern Canada, this benthic foraminiferal assemblage is Kimmeridgian-Tithonian in age.

Planktonic foraminifera include Globuligerina bathoniana (abundant), common Globuligerina oxfordiana, rare Globuligerina tojeiraensis, rare Petaloglobigerina simmonsi and rare Conoglobigerina grigelisi. No Conoglobigerina helvetojurassica was observed, a species common in the upper part of the underlying Tojeira Formation. Some Globuligerina oxfordiana specimens have a reticulate wall texture, a feature taken up in the section on Evolution.

References: Ascoli et al. (1984) [38]; Stam (1986) [20]; Williamson and Stam (1988) [39]. Tithonian, Hungary (x)

Study: Co-author A.W. and colleagues in 2019 visited the Paprét-árok profile in the Gerecse mountains of Hungary. This locality is described with outcrop details and a Tithonian planktonic foraminiferal assemblage in [40]. It turns out the locality does not exist, and its publication and description are based solely on archival data. The locality originally was a railway cut.

Locality: Paprét-árok, Gerecse Mts, Hungary (x).

Lithology and Zone-Age: In the Paprét-árok profile the succession begins with red radiolarite (Lókút Radiolarite Formation) of Middle Jurassic-Kimmeridgian age. It is followed upwards with a massive and hard bank about $75 \mathrm{~cm}$ in thickness, grey, pink and purple in colour. This massive bank is subdivided in five beds numbered 6 to 2, from the base to the top: Beds 6-7 belong to the Beckeri and the Hybonotum Zones, Bed 5 questionably to the Darwini Zone and Bed 4 questionably to the Fallauxi Zone, all considered early Tithonian in age. Limestone Beds 3 and 2 are not zoned, but considered as probably late Tithonian in age. Above this massive limestone bank occur grey marl and breccia layers, belonging to the Lower Cretaceous Bersek Marl Formation.

Microfossil assemblage: 'Protoglobigerinids' are described from bed 5 ? Darwini Zone using thin sections and free specimens obtained with weak acetic acid. The authors consider the planktonic foraminiferal assemblage to be monospecific, with a species transitional between Globuligerina oxfordiana and Favusella hoterivica, but no pore features and wall texture can be determined, making the interpretation tentative. Stratigraphically higher-up, it states that the same section might yield Berriasian planktonic foraminifera, but none are listed.

Reference: Görög and Wernli (2004) [40].

Tithonian-Valanginian, North Africa

Other localities: There is a meagre record of unspecified planktonic foraminifera in thin sections from Tethyan limestones of Tithonian through Valanginian age in N. Africa and Central Europe [40].

\section{Early Berriasian, Crimea}

Study: For our study of Mesozoic planktonic foraminifera, Ludmila Kopaevich (Moscow) obtained samples from the Tonas River Basin in E. Crimea, Russia. The hard marly sediment interval is assigned to the Jacobi ammonite Zone, early Berriasian, not far above the Jurassic-Cretaceous boundary. The Tonas River Basin is a locality from which Gorbachik and Poroshina [41] described Globuligerina caucasica and Globuligerina gulekhensis.

Locality, with coordinates: Outcrop $2 \mathrm{~km}$ south of the village Krasnoselivka in the Tonas Basin, Crimea, Russia. Geographic coordinates are 44.927712 N, 34.634905 E.

Zones, stage: Calcareous nannofossil Zone CC2, late early to middle Berriasian;

Ammonites of the Jacobi and Grandis subzones of the Jacobi Zone of early Berriasian age. Benthic foraminifera of the Protopeneroplis ultragranulatus-Siphoninella antiqua Zone and a younger one-Quadratina tonassica-Siphoninella antiqua Zone.

Microfossil assemblage: Fairly well-preserved benthic foraminifera, with Epistomina stellicostata, E. volgensis and E. uhligi, Lamarckina sp., common Neobulimina sp., Patellina sp., 
Lenticulina spp., several nodosariid taxa, Bigenerina sp., Spiroplectammina spp., Textularia sp., Trochammina sp.

Sample Cr1 contains about 100 specimens of planktonic foraminifera taxa, all microperforate, including with frequent specimens Favusella hoterivica, with common specimens Clavihedbergella eocretacea and Conoglobigerina gulekhensis and with less than 10 specimens each of the taxa Hedbergella aff. similis, ?Favusella sp., Hedbergella aff. handousi and ? Globuligerina sp.

Only Conoglobigerina gulekhensis was previously known from Berriasian strata, and this only from two regions, Crimea and Azerbaijan. Favusella hoterivica (Subbotina) with certainty only is known from Valanginian through Aptian marine strata, and the other taxa only from Valanginian, Hauterivian or even younger stratigraphic intervals. All taxa are of Tethyan or sub-Tethyan origin.

Note: As outlined in some detail in the geological history study by Nikishin et al. (2017) [42], the Crimea region underwent late Berriasian vertical movements, leading to a regional unconformity with erosion and karstification of underlying strata. The Krasnoselivka section preserves non-karstified Berriasian limestones, subject of our study.

References: Arkadiev et al. (2005) [43]; Gorbachik and Poroshina (1979) [41]; Gradstein et al. (2018) [44].

Berriasian-early Valanginian, Scotian Shelf, offshore eastern Canada

Study: In 2019, author F.G. studied foraminifera in micropaleontology slides and washed residues $(65-250 \mu \mathrm{m})$ from exploration well samples stored with the Geological Survey of Canada, Bedford Institute of Canada, Dartmouth, NS, Canada.

Locality: Exploration wells with interval studied: Oneida O-25, 8630-9460'below casing point at $6876^{\prime}$; Onondaga E-84, $11730-11810^{\prime}$, below casing point at $8121^{\prime}$; Glenelg $\mathrm{J}-48,4165-4155 \mathrm{~m}$, below casing point at $4134 \mathrm{~m}$.

Zone, stage: Using dinoflagellates and benthic foraminifera, the studied interval is assigned a Berrisian-early Valanginian age.

Microfossil assemblage: In total about 50 specimens of Favusella hoterivica were obtained, many pyritized and with good wall texture details. Some questionable Conoglobuligerina aff. gulekhensis were found, but preservation is insufficient to provide reliable identification. Benthic foraminifera include Lenticulina busnardoi, Epistomina minireticulata, E.stellicostata, Neobulimina sp, Discorbis aff. valdendisensis, Discorbis sp., agglutinated indet. Micro gastropods are common to abundant, as they are in the Kimmeridgian Tojeira Formation in Portugal.

References: Ascoli (1976) [45]; Wernli et al. (1995) [46]; Barss et al. (1979) [47].

Berriasian-early Valanginian, North Mexico (x)

Study: North Mexico calpionellid publication with thin sections.

Locality: Taraises Formation, north Mexico

Zone, stage: Calpionellid assemblages assigned to Berriasian-early Valanginian.

Microfossil assemblage: Poor thin-section illustrations of Conoglobigerina gulekhensis, Caucasella hoterivica, Compactogerina sp. and Gorbachikella sp. by Omaña et al. (2017) [48] from Berriasian-early Valanginian limestones of the Taraises Formation in north Mexico. The images are non-determinate, but the illustration on Figure 5 of Omaña et al. (2017) likely is Favusella hoterivica. The type of the monotypic genus Compactogerina is coarse perforate and belongs to Neogene Neogloboquadrina pachyderma [1,3]. Lourdes Omaña kindly communicated to Gradstein (May 2018) that it is currently not advised to visit the Mexican site due to drug-related violence. 


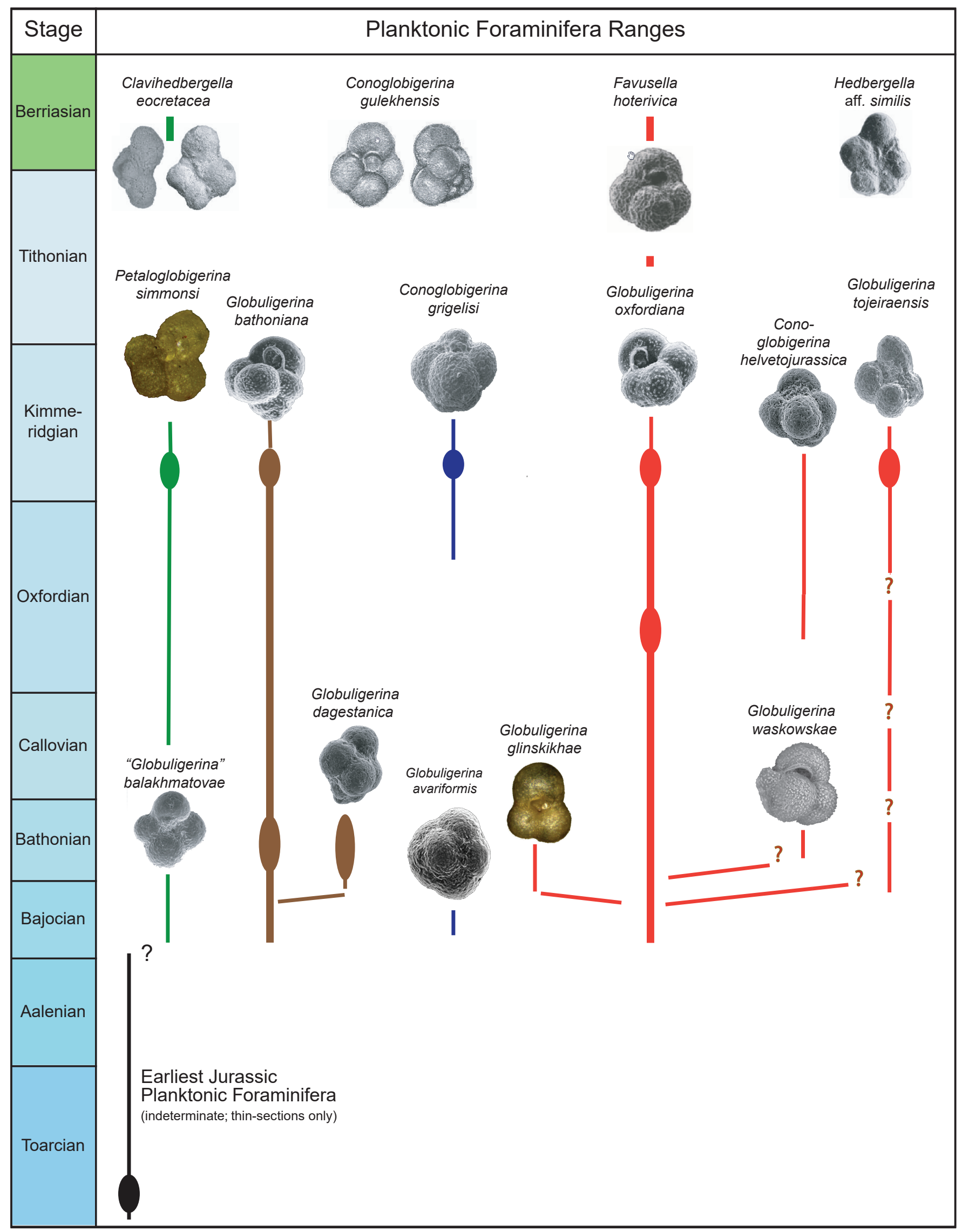

Figure 5. Stratigraphic ranges and evolution of Jurassic planktonic foraminifera. For details, see text. 
Reference: Omaña et al. (2017) [48].

\section{Biochronology}

The Jurassic planktonic foraminifera are subdivided in three genera and eleven species, including Globuligerina oxfordiana (Grigelis), Gobuligerina glinskikhi (Gradstein and Waskowska), Gobuligerina bathoniana (Pazdrowa), Globuligerina dagestanica (Morozova), Globuligerina balakhmatovae (Morozova), Globuligerina avariformis (Kasimova), Globuligerina waskowskae Gradstein, Globuligerina tojeiraensis Gradstein, Conoglobigerina helvetojurassica (Haeusler), Conoglobigerina grigelisi Gradstein and Petaloglobigerina simmonsi Gradstein. In addition, for evolutionary insight we include here the three Berriasian species Favusella hoterivica (Subbotina), Clavihedbergella eocretacea (Neagu), and Conoglobuligerina gulekhensis (Gorbachik and Poroshina).

Figures A1-A5 (Appendix A) provide light microscope and SEM images of the Jurassic species, grouped by gross morphologic similarity between taxa. Figure A6 (Appendix A) shows two key Berrisian planktonic foraminifera, descendants of Jurassic species as postulated in [44].

Globuligerina, with a smooth to pustulose test surface texture appeared in Toarcian (late Early Jurassic) time, and Conoglobigerina, with a rough reticulate test surface texture in Oxfordian (early Late Jurassic) time. Petaloglobigerina, with a petaloid last whorl and one or more twisted and claviform chambers evolved in early Kimmeridgian time from Globuligerina balakhmatovae.

Table 1 list the oldest age level of formally described Jurassic planktonic foraminifera species, and Figure 4 depicts the FAD of genera and species in a simple stratigraphic column, calibrated to ammonite and nannofossil stratigraphy, as outlined below. The biochronology uses the GTS2020 geochronologic scale. Event age uncertainty beyond the duration of the ammonite zone(s) in which FAD's were determined is not touched upon on in this study.From older to younger the FAD's in Ma of the genera are:

Table 1. Listing of the oldest age level and the level of first formal description of Jurassic planktonic foraminifera.

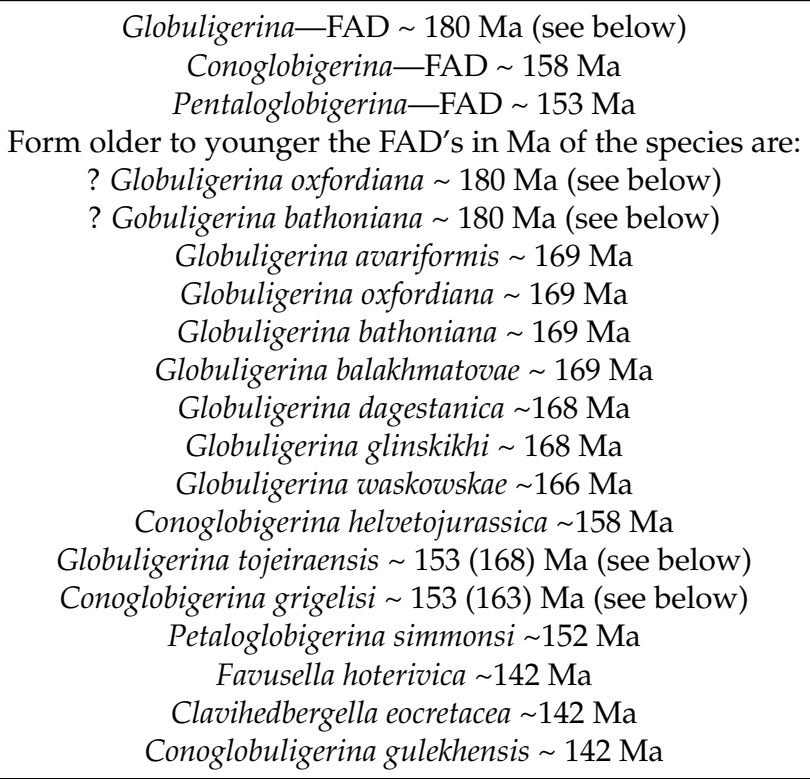

The study of Wernli [11] on thin sections from Toarcian limestone samples in the Domuz Dag mountain chain of SE Turkey provided by. Poisson (Paris) from his thesis [49] documents the oldest known occurrence of planktonic foraminifera. Curiously, this is the only record in the whole world of this oldest known assemblage. Hence, planktonic foraminifera appeared in the Toarcian around $180 \mathrm{Ma}$ ago. The youngest Jurassic occur- 
rence of this group is documented by Görög and Wernli [40] describing a single taxon of planktonic foraminifera (extracted with acetic acid) in Tithonian age samples from Hungary. Hence, Jurassic planktonic foraminifera range from Late Toarcian (Bifrons- Variabilis ammonite Zones) through Late Tithonian (C. alpina calpionellid Zone).

Unfortunately, the Toarcian through Aalenian record is only known from thin-sections, but we consider that an often larger and higher spired form similar to Gobuligerina bathoniana and a smaller, lower spired form similar to Globuligerina oxfordiana occur in these thin-sections. This needs better documentation with well-preserved free specimens. Test size difference in itself may not be a taxonomic feature, and often has more to do with growth conditions in optimal or sub-optimal environments, selective sediment sorting, water masses and vertical biota distribution, and other hard to evaluate factors in fossil material.

The LAD's of these taxa is not known, but all Jurassic species have disappeared before Cretaceous (143 Ma).

From the stratigraphic record outlined in the 'Stratigraphic inventory' chapter it is clear that Globuligerina oxfordiana, Globuligerina bathoniana and Globuligerina balakhmatovae have a long stratigraphic range, spanning several stages for 20 myr or more. Conoglobigerina helvetojurassica has a much shorter stratigraphic range, spanning two stages for $10 \mathrm{myr}$ or more. The single observation that the regionally restricted Conoglobigerina grigelisi appears in Callovian -Oxfordian strata on the Grand Banks means its common presence in the Kimmeridgian of Portugal is not an FAD event. The regionally restricted species Globuligerina dagestanica, Globuligerina glinskikhae, Globuligerina avariformis and Globuligerina waskowskae may have been stratigraphically short-lived. A special case is Globuligerina tojeiraensis, first described by us from the Kimmeridgian of central Portugal. Here it is consistently present in long series of consecutive samples, with a stable and unique test morphology and with frequent specimens. Comparable tests occur with few specimens in Middle Jurassic samples from Dagestan and Poland, hence Globuligerina tojeiraensis might have appeared earlier than shown here (cf. Gradstein, 2017 [28]).

\section{Tentative Evolutionary Lineages}

As outlined in Figure 5 (which updates Figure 3G.1 in [50]) we postulate that within the Jurassic and earliest Cretaceous four lineages of planktonic foraminifera occur, which for graphic clarity are shown with green, brown, blue and red stratigraphic lines. We stress that these lineages are hypothetical and need more stratigraphic data. Two taxa, Petaloglobigerina simmonsi and Globuligerina oxfordiana are postulated to be ancestral to Cretaceous taxa as indicated in Figure 5 and discussed in some detail in [31]. This study of the planktonic foraminifera of the lower Berriasian in Crimea also determined Conoglobuligerina gulekhensis and Hedbergella aff. similis, for both of which no potential Jurassic ancestral link is established.

The 'green group' is monotypic and consists of Globuligerina balakhmatovae evolving during Kimmeridgian time in Petaloglobigerina simmonsi.

The ancestry of Globuligerina balakhmatovae is not clear. A possible morphological transition exists to Oberhauserella aff. parocula described by Wernli and Görög [51] from SE France, but this requires refinement of our knowledge on the stratigraphic appearance and test morphology of both taxa. A detailed study of wall textures should be undertaken. An issue is that the holotype of Globuligerina balakhmatovae falls outside the common Globuligerina balakhmatovae morphology as we observe it in our rich topotype material from Dagestan; the holotype test is more inflated and chambers are not petaloide or ovate.

There is no stratigraphic record of the low-spired, and often claviform chambered Petaloglobigerina simmonsi in post (early) Kimmeridgian strata. Based on a general similarity in test morphology, Gradstein et al. [44] proposed that this taxon might have evolved in Clavihedbergella eocretacea in early Berriasian time.

The 'brown group' includes Globuligerina dagestanica (Morozova) and the common species Globuligerina bathoniana, all higher spired trochoid morphotypes with an arch to 
looped aperture and commonly a bulla. Essentially, we can distinguish one taxon with a more symmetrical and regular trochospire with four chambers in the last whorl (bathoniana type), and another taxon with more irregular (or sometimes triangular) trochospire with 3 , 3-4 or 4 chambers in the last whorl (dagestanica type). In our opinion, Globuligerina jurassica (Hofman) might be a local and often aberrant variant of Globuligerina dagestanica.

The 'blue group' consists of Globuligerina avariformis (Kasimova) and Conoglobigerina grigelisi (Gradstein), both of which do not have a geographically widespread record. The two species typically have a last whorl that strongly embraces earlier ones, such that the test almost appears involute. A possible evolutionary line age is postulated from the compact Globuligerina avariformis into the equally, or even more compact Conoglobigerina grigelisi. The latter acquires a reticulate wall sculpture. Its youngest record is middle Kimmeridgian. One issue, common to other Jurassic planktonic foraminiferal species is that we do not have a stratigraphic and sampling record leading from one species to the other species. We refrain to speculate on the ancestry of Globuligerina avariformis.

The 'red group' includes Globuligerina oxfordiana, Globuligerina glinskikhae, Globuligerina tojeiraensis and the inferred lineage from Globuligerina waskowskae to Conoglobigerina helvetojurassica. These are low- to medium high-spired morphotypes, with spherical-globular or radially somewhat elongated chambers, narrow to wide umbilicus, large last whorl and arch to looped aperture with lip. In well-preserved and typical Globuligerina oxfordiana the looped aperture is very slightly offset from the umbilicus. A stratigraphic trend exists in this taxon to a more reticulate wall texture with the umbilicus opening up.

Gorbachik [52] showed the onset of reticulation on older chamber of a specimen of this species; this is clearly an ontogenetic feature in rare specimens of some assemblages. If ontogeny recapitulates evolution, this wall texture change strengthens our postulation that Jurassic Globuligerina oxfordiana is ancestral to Cretaceous Favusella hoterivica. The close morphological comparison and overlap in wall texture features, makes it viable to consider Globuligerina oxfordiana to be the ancestor of Favusella hoterivica. Both taxa are illustrated in Figure 5. It is interesting, as listed above that reticulate Globuligerina oxfordiana occur in the Middle Kimmeridgian of Portugal.

The species Globuligerina tojeiraensis, with elongated chambers and wide-open umbilicus is frequent in the Kimmeridgian of Portugal. Its overlap in morphology with Globuligerina oxfordiana suggests the latter to be ancestral. Figure 5 tentatively shows that the taxon might have originated earlier and a special study should be undertaken of Globuligerina with elongated chambers. The origin of Globuligerina oxfordiana is shrouded in mystery.

The discovery and description in Gradstein and Waskowska [2] of well-preserved Globuligerina waskowskae with a test morphology much alike Conoglobigerina helvetojurassica makes it attractive to consider the former taxon to be ancestral, although this likely is a case of broad morphological resemblance due to the strongly embracing last whorl. The principal new feature is the distinctive reticulate wall surface texture of Conoglobigerina helvetojurassica, appearing in Middle Oxfordian.

In summary, and as illustrated in Figure 5 the planktonic foraminifera appeared during Toarcian time (but no free specimens record) and occurred with at least eight taxa of one genus in Bajocian-Bathonian. The Oxfordian-Kimmeridgian planktonic foraminiferal record consists of six taxa in four genera. A faunal change-over, which is not well documented led to the survival of only one taxon, most likely Gobuligerina oxfordiana in the Tithonian.

Author Contributions: All authors have read and agreed to the published version of the manuscript. Institutional Review Board Statement: Not applicable.

Informed Consent Statement: Not applicable. 
Acknowledgments: A.W. thanks the A.G.H. (Project no. 16.16.140.315). Project no. 0331-2019-0005 of the Program of Fundamental Scientific Research supported L.G. for this study. F.G. thanks Jeremy Young (UcL, London, UK) for his outstanding assistance to keep Mikrotax at http:/ / www.mikrotax. org updated with the formal taxonomy and the stratigraphy of Jurassic planktonic foraminifera.

Conflicts of Interest: The authors declare no conflict of interest.

\section{Appendix A}

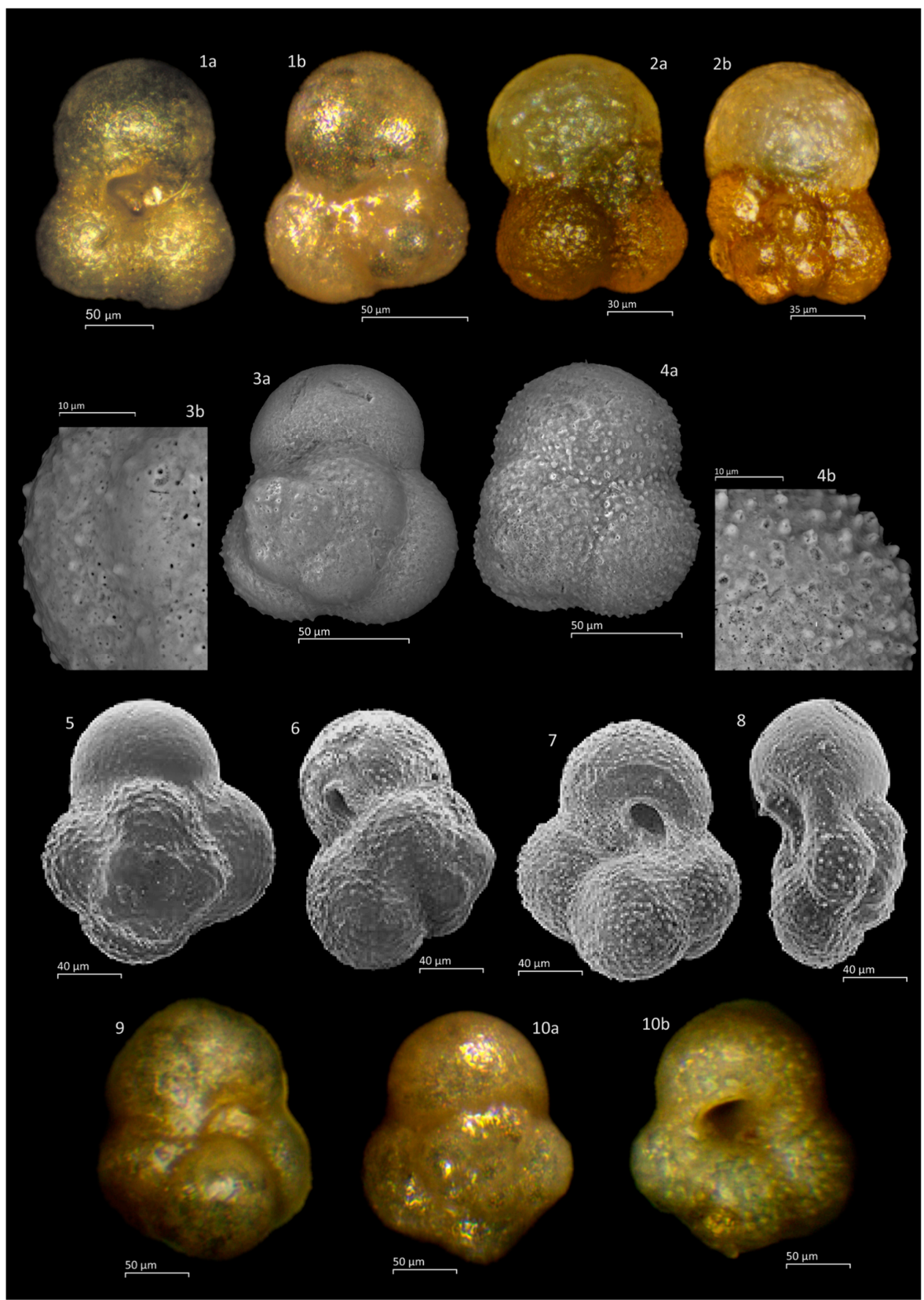

Figure A1. Globuligerina glinskikhae Gradstein and Waskowska. Subfigures 1a,b-holotype, sample 6, Morrisi Ammonite Zone, Middle Bathonian, Gnaszyn, Poland. Subfigures 2a,b-paratype, sample 8, Parkinsoni Zone, Upper Bajocian, Khouroukra, Dagestan. Subfigures $\mathbf{3} \mathbf{a}, \mathbf{b}$ and $\mathbf{4 a}, \mathbf{b}$-paratypes, sample 6, Morrisi Zone, Middle Bathonian, Poland; note the microperforate and pustulose wall with scattered pore mounds. Globuligerina oxfordiana (Grigelis). Subfigures 5-7, Oxfordian of Upper Volga, Russia. Subfigure 8, Mariae Zone, Lower Oxfordian near Le Havre, France (subfigures 5-8 from [3]). Subfigures 9 and 10a,b, sample 6, Morrisi Zone, Middle Bathonian, Poland. 

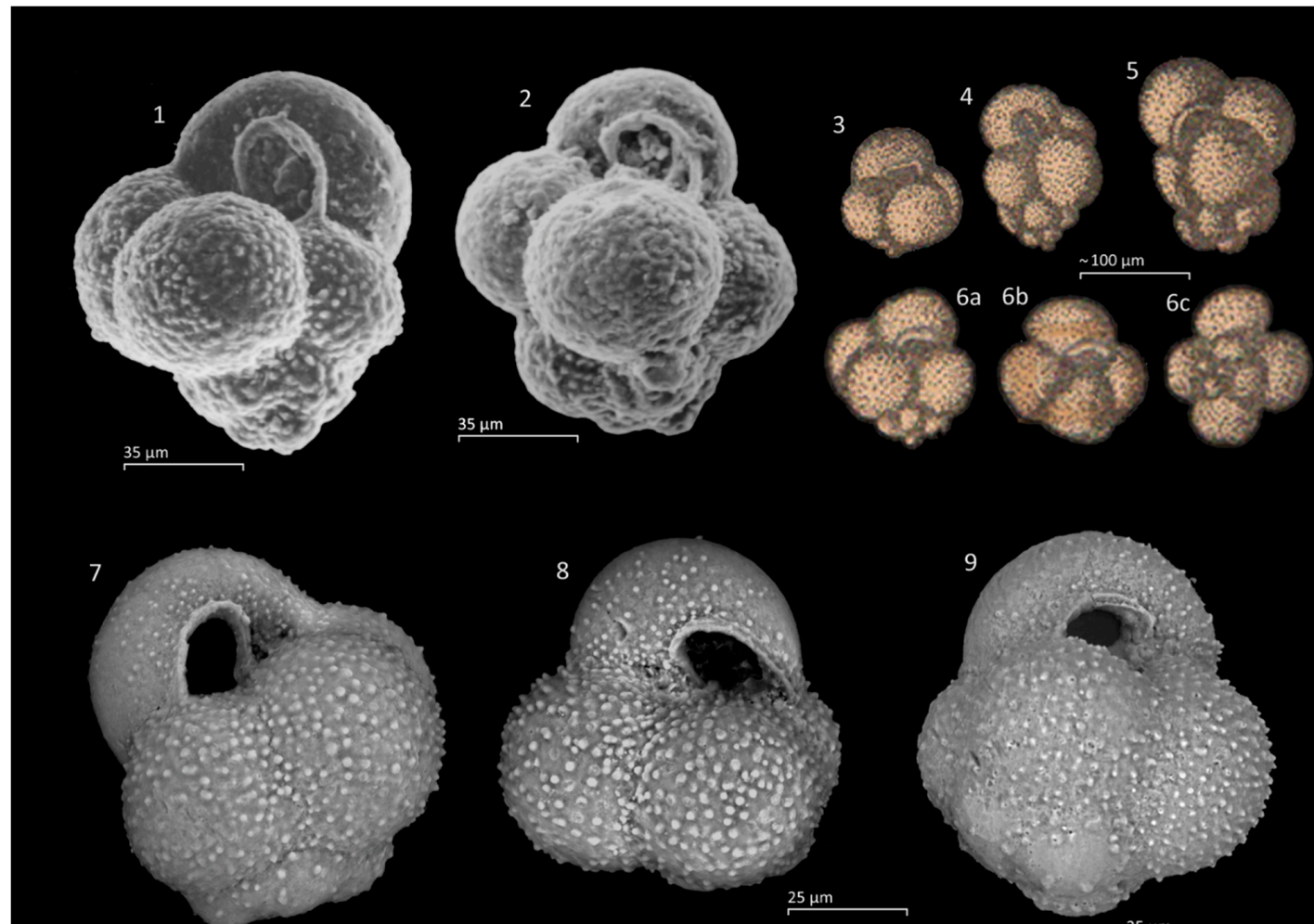

$25 \mu \mathrm{m}$

$25 \mu$

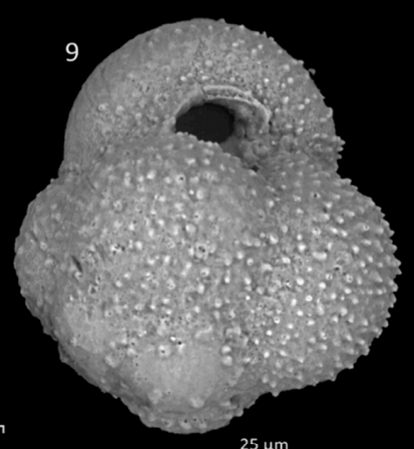

$25 \mu \mathrm{m}$
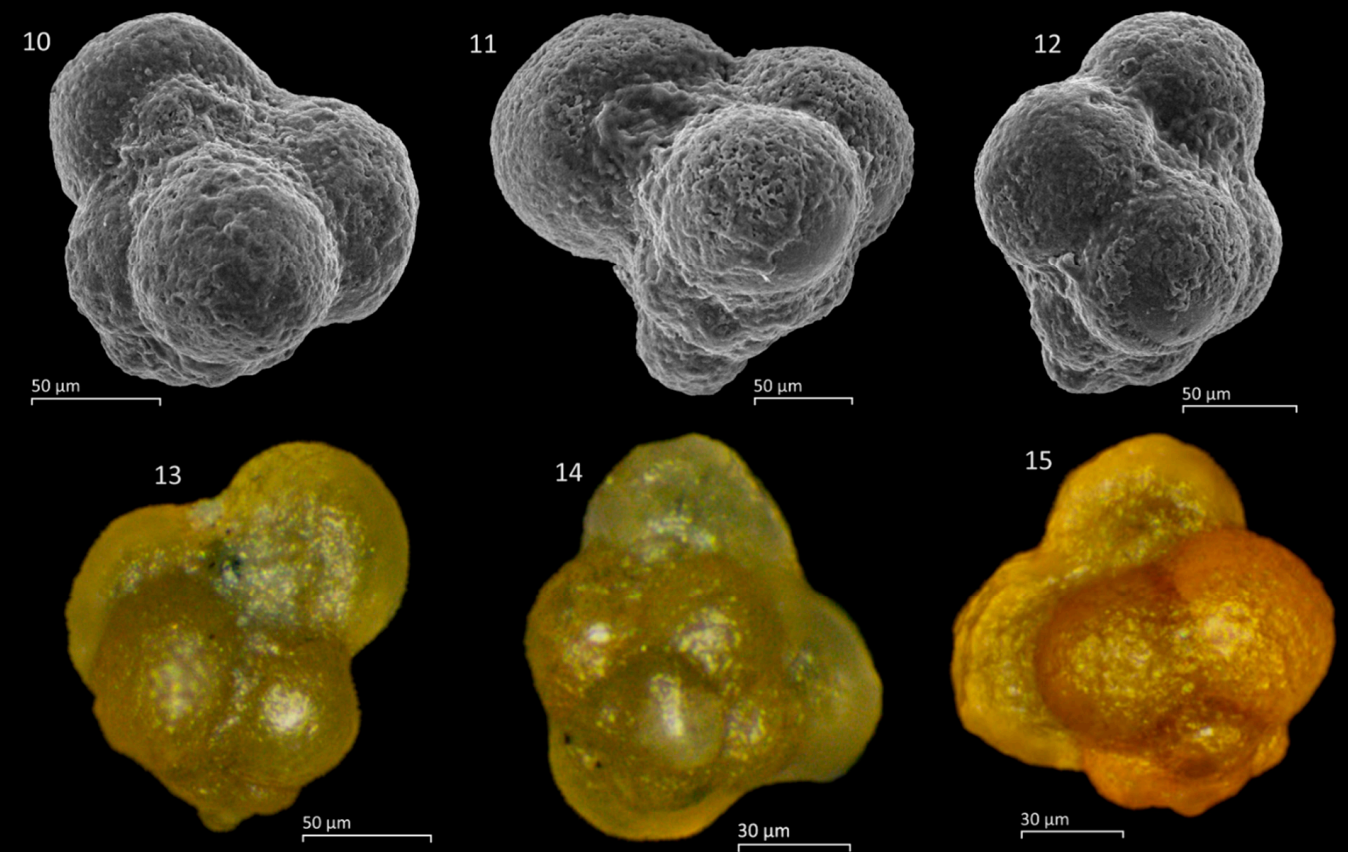

Figure A2. Globuligerina bathoniana (Paszdrowa). Subfigures 1 and 2, Eider M-75 well, cts. 8260-8290', Garantella spp. Zone, Bajocian-Bathonian, Grand Banks, Canada. Subfigures 3-6, re-illustration of Bathonian type species drawings provided by Olga Pazdrowa to Felix Gradstein. Specimen height 140-180 $\mu \mathrm{m}$. Subfigures 7-9, sample 6, Morrisi Zone, Middle Bathonian, Gnaszyn, Poland.Globuligerina dagestanica (Morozova). Subfigures 10-15, topotype specimens from samples 8 and 9, Khouroukra section, Late Bajocian, Dagestan. 


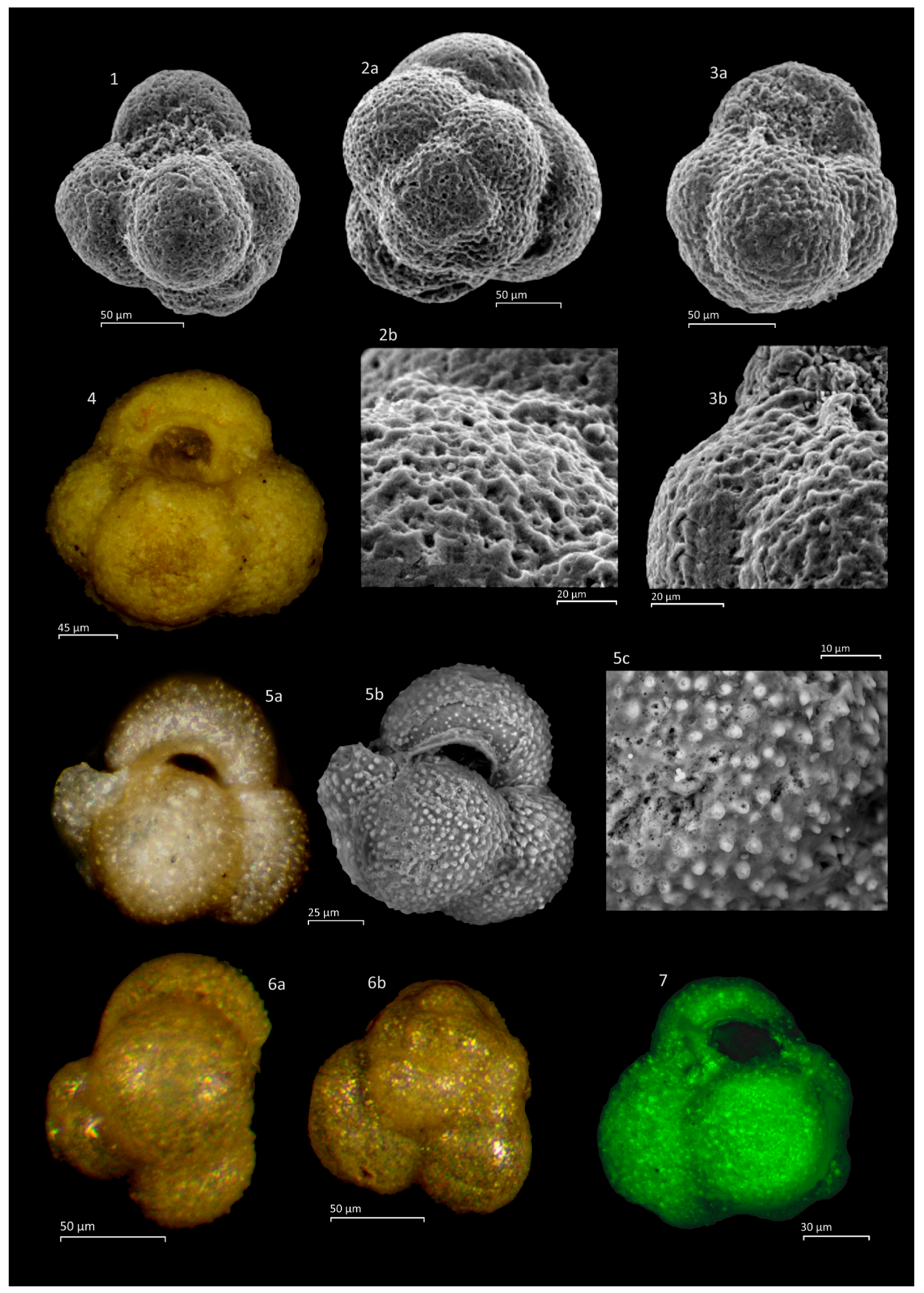

Figure A3. Conoglobuligerina helvetojurassica (Haeusler). Subfigures 1-3, holotype and paratype specimens from sample 4.mid, Eisengraben Section, Birmerstorfer Schichten, Transversarius Zone, Middle Oxfordian, Canton Aargau, Swizerland; note reticulate wall texture. Subfigure 4, sample 24/2P, Tojeira Formation, Lower Kimmeridgian, Montejunto, Portugal. Globuligerina waskowskae Gradstein. Subfigures 5-7, holotype and paratype specimens, sample 6, Morrisi Zone, Middle Bathonian, Gnaszyn, Poland; note microperforate wall with small, regularly distributed pustules, many with pore mounds. 


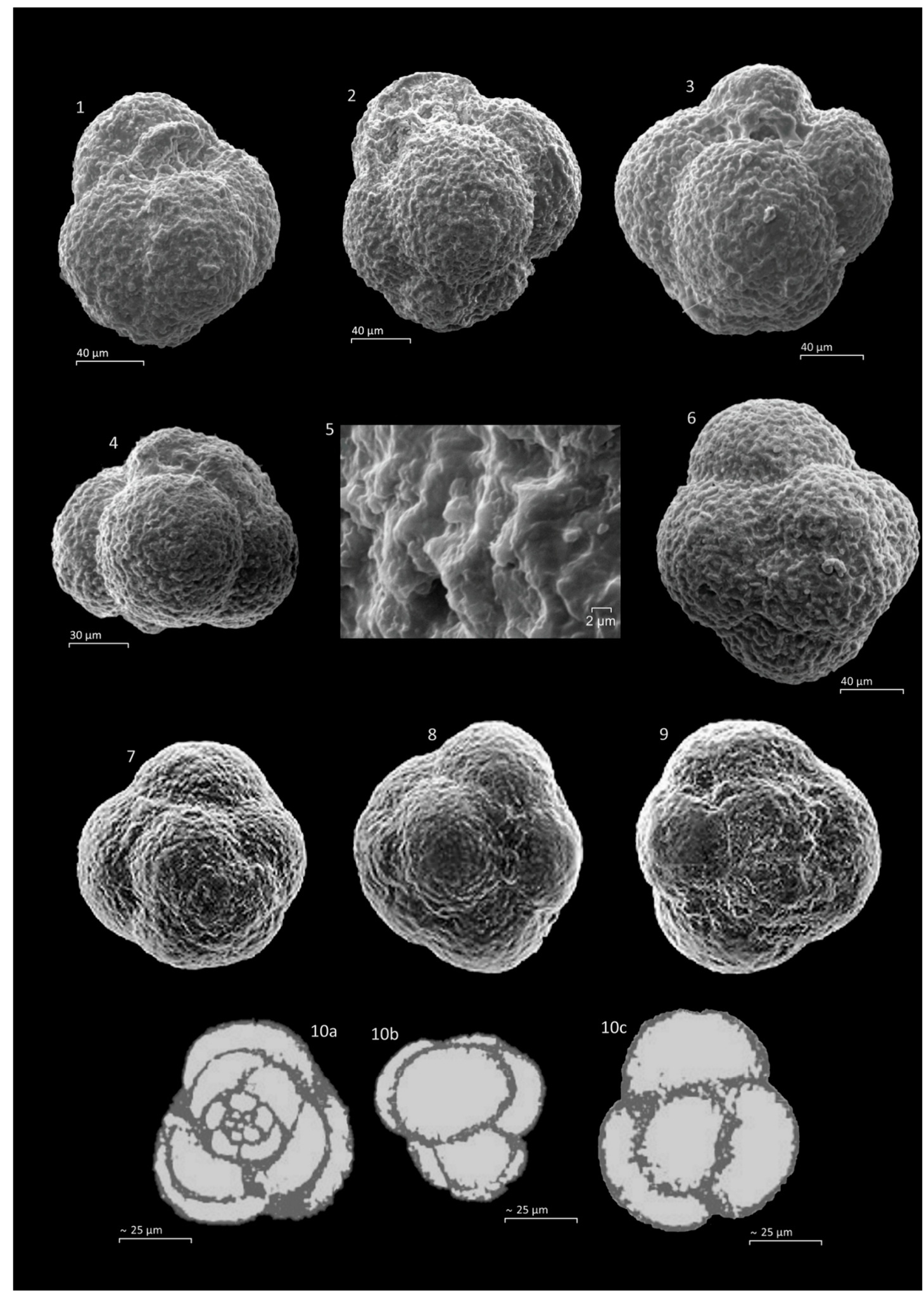

Figure A4. Conoglobigerina grigelisi (Gradstein). Subfigures 1-6, holotype and paratype specimens in sample 24/2P, Tojeira Formation, Lower Kimmeridgian, Montejunto, Portugal. Globuligerina avariformis (Kasimova). Subfigures 7-9. Upper Bajocian, Negramkoye Gorge, Aras River, Nakhichevan, Azerbijan; metatypes donated by Dr. Kasimova to the Natural History Museum (London, UK) diameter of $320 \mu \mathrm{m}$ may be an error. Subfigure 10a-c, holotype drawing by Kasimova and Aliyeva [16] $\times 90$. 


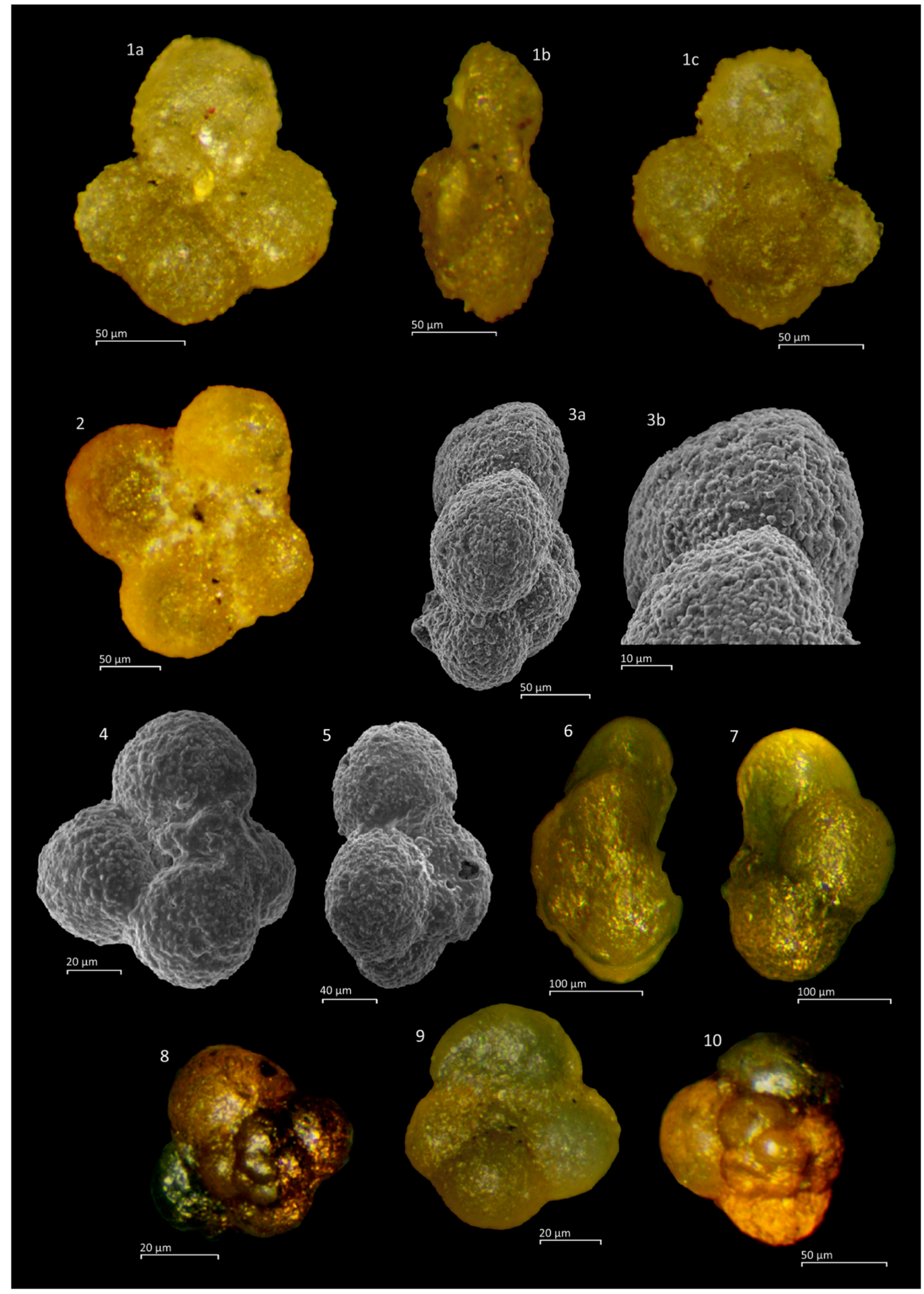

Figure A5. Petaloglobigerina simmonsi Gradstein. Subfigures 1 and 2, holotype and paratype specimens, sample 10, Section 1 , Tojeira Formation, lower Kimmeridgian, Montejunto, Portugal. Subfigure 3a, b, paratype specimen, samples 6-28, upper Tojeira Fm., lower Kimmeridgian, Montejunto, Portugal; note the four chambered last whorl with pointed periphery and the densely pustulose wall texture. Globuligerina balakhmatovae (Morozova). Subfigure 4, cuttings sample 8360', Eider well, Grand Banks, Bajocian-Bathonian; wall texture pustulose. Subfigure 5, sample 24/2P, Tojeira Formation, Montejunto, Portugal, lower Kimmeridgian; wall texture coarsely pustulose. Subfigures 6-10, side, umbilical and spiral views of topotypes of Globuligerina balakhmatovae (Morozova), sample 8, Parkinsonii Zone, Upper Bajocian, Khouroukra, Dagestan. 


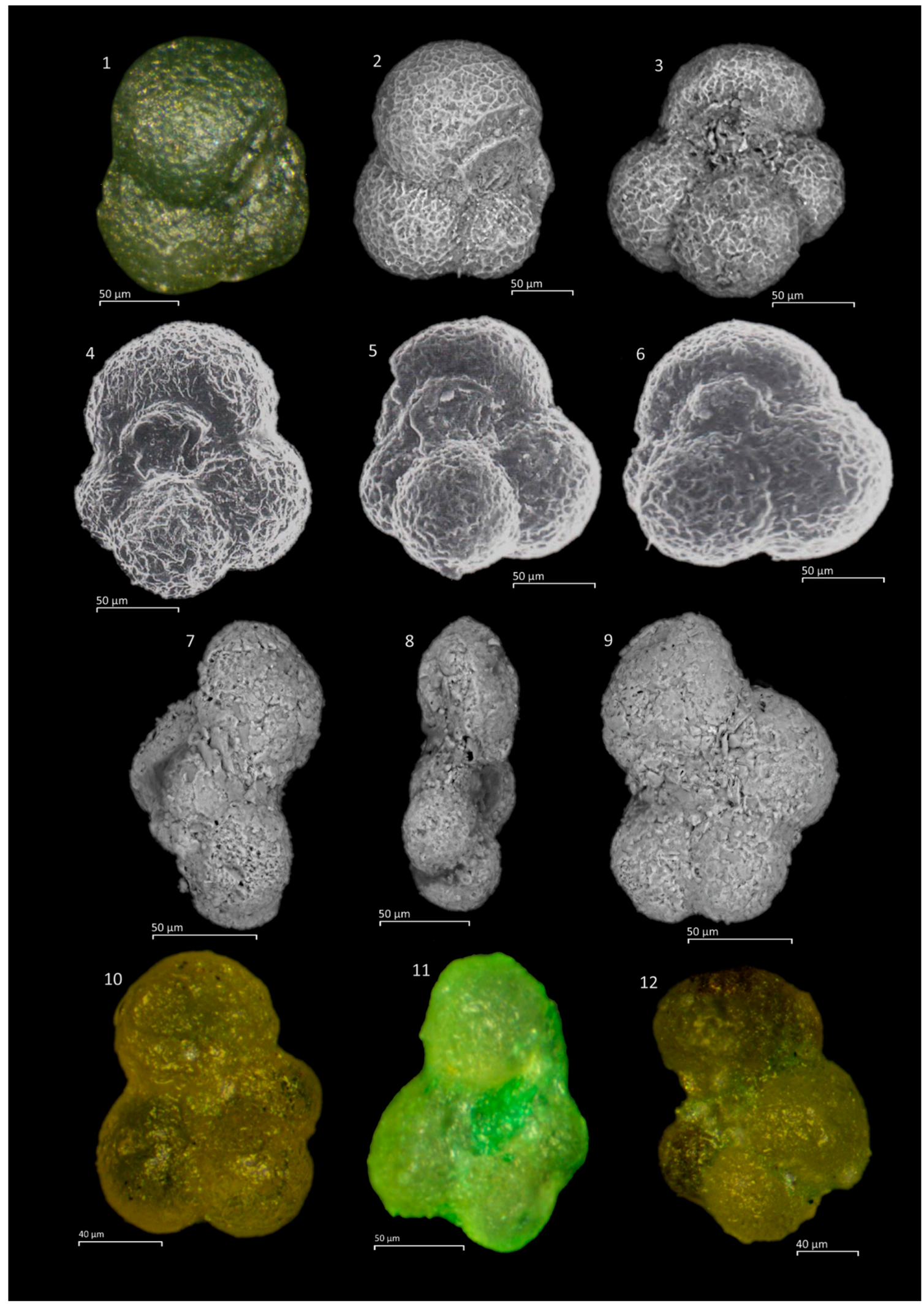

Figure A6. Favusella hoterivica (Subbotina). Subfigures 1-6, Oneida 0-25 well, cts 8760-9460', Berriasian, E. Canada (Figures 4-6 from Plate II in [47] with permission from the authors). Clavihedbergella eocretacea (Neagu). Subfigures 7-12, sample Cr1 of Berriasian age, Krasnoselivka section, Crimea, Russia. 


\section{References}

1. Gradstein, F.; Gale, A.; Kopaevich, L.; Waskowska, A.; Grigelis, A.; Glinskikh, L. The planktonic foraminifera of the Jurassic. Part I: Material and taxonomy. Swiss J. Palaeontol. 2017, 136, 187-257. [CrossRef]

2. Gradstein, F.; Waskowska, A. New insights into the taxonomy and evolution of Jurassic planktonic foraminifera. Swiss J. Palaeontol. 2021, 140, 1-12. [CrossRef]

3. Gradstein, F.; Gale, A.; Kopaevich, L.; Grigelis, A.; Glinskikh, L.; Görög, Á.; Waskowska, A. The planktonic foraminifera of the Jurassic. Part II: Stratigraphy, palaeoecology and palaeobiogeography. Swiss J. Palaeontol. 2017, 136, 259-271. [CrossRef]

4. Gradstein, F. The planktonic foraminifera of the Jurassic. Part III: Annotated historical review and references. Swiss J. Palaeontol. 2017, 136, 273-285. [CrossRef]

5. Gradstein, F.M.; Ogg, J.G.; Schmitz, M.D.; Ogg, G.M. The Geologic Time Scale 2020; Elsevier: Amsterdam, The Netherlands, 2020; 1357 p.

6. Salvador, A. (Ed.) International Stratigraphic Guide; Geological Society of America: Boulder, CO, USA, 1994; 214p.

7. Berggren, W.A.; Van Couvering, J.A.; Cohee, G.V.; Glaessner, M.F.; Hedberg, H.D. Biochronology. In Contributions to the Geologic Time Scale; American Association of Petroleum Geologists: Tulsa, OK, USA, 1978; pp. 39-55. [CrossRef]

8. Ogg, J.G.; Ogg, G.M.; Gradstein, F.M. A Concise Geologic Time Scale; Elsevier: Amsterdam, The Netherlands, 2016 ; p. 234.

9. Hesselbo, S.; Ogg, J.; Ruhl, M.; Hinnov, L.; Huang, C. The Jurassic Period. In Geologic Time Scale 2020; Elsevier: Amsterdam, The Netherlands, 2020; Volume 2, pp. 955-1021.

10. Gale, A.; Mutterlose, J.; Batenburg, S.; Gradstein, F.; Agterberg, F.; Ogg, J.; Petrizzo, M. The Cretaceous Period. Geologic Time Scale 2020 2020, 2, 1023-1086. [CrossRef]

11. Wernli, R. Les protoglobigerines (foraminifers) du Toarcien et de L'Aalenien du Domuz Dag (Taurus Occidental, Turquie). Eclogae Geol. Helv. 1988, 81, 661-668.

12. Wernli, R. Les protoglobigerines (Foraminifers) du Bajocien inferieur des sofs (Rif, Maroc). Eclogae Geol. Helv. 1987, 80, 817-829.

13. Apthorpe, M. Middle Jurassic (Bajocian) planktonic foraminifera from the northwest Australian margin. J. Micropalaeontology 2020, 39, 93-115. [CrossRef]

14. Wernli, R.; Görög, A. Protoglobigerinids (foraminifera) acid extracted from Bajocian limestones (Hungary). Rev. Esp. Micropal. 1999, 31, 419-426.

15. Bignot, G.; Janin, M.-C. Découverte de Globuligerina oxfordiana (Foraminifères planctonique) dans le Bajocien stratotypique de la Falaise des Hatcheetts (Sainte-Honorine-de-Pertes, Calvados, France). C.R. Acad. Sc. Paris t. 1984, 298, 751-756.

16. Kasimova, G.K.; Aliyeva, D.G. Planktonic foraminifera of the Middle Jurassic beds of Azerbaijan. Vopr. Palaeontol. I Stratigr. Azerbaijana 1984, 479, 8-19. (In Russian)

17. Simmons, M.D.; BouDagher-Fadel, M.K.; Banner, F.T.; Whittaker, J.E. The Early Evolutionary History of Planktonic Foraminifera. In The Early Evolutionary History of Planktonic Foraminifera; Springer: Berlin/Heidelberg, Germany, 1997; pp. 17-53.

18. Morozova, V.G.; Moskalenko, T.A. Foraminiferes planktoniques des depots limitrophes du Bajocien et du Bathonien du Daghestan central (Nord-East du Caucase). Voprosy Paleontologii i Stratigrafii Azerbaijana 1961, SSSR 5, 3-30.

19. Gradstein, F.M. Biostratigraphy and biogeography of Jurassic Grand Banks Foraminifera. Maritime Sediments 1976, 1, 557-583.

20. Stam, B. Quantitative analysis of Middle and Late Jurassic Foraminifera from Portugal, and its implications for the Grand Banks of Newfoundland. Utrecht Micropal. Bull. 1986, 34, 167.

21. Pazdrowa, O. Bathonian Globigerina of Poland. Rocz. Pol. Towarz. Geol. 1969, 39, 41-56.

22. Smoleń, J. Faunal dynamics of foraminifer assemblages in the Bathonian (Middle Jurassic) ore-bearing clays at Gnaszyn, Krakow-Silesia Homocline, Poland. Acta Geol. Pol. 2012, 62, 403-419.

23. Gedl, P.; Kaim, A.; Leonowicz, P.; Boczarowski, A.; Dudek, T.; Kędzierski, M.; Ress, J.; Smoleń, J.; Szczepanik, P.; Sztajner, P.; et al. Palaeoenvironmental reconstruction of Bathonian (Middle Jurassic) ore-bearing clays at Gnaszyn, Kraków-Silesia Homocline, Poland. Acta Geol. Pol. 2012, 62, 463-484.

24. Bordalo da Rocha, R. Estudo estratigrafico e palaeontologico do Jurassico do Algarve occidental. In Ciencias da Terra 2; Universidade Nova de Lisbon: Lisbon, Portugal, 1976; 114p.

25. Bignot, G.; Guyader, J. Découverte de foraminifères planctoniques dans l'Oxfordien du Havre (Seine-Martitime). Rev. De Micropaléntologie 1966, 2, 104-110.

26. Samson, Y.; Janin, M.-C.; Bignot, G. Les globigerines (foraminiferes planctoniques) de L'Oxfordien inferieur de Villes-Sur-Mer (Calvados, France) dans leur gisement. Rev. Palaeobiol. 1992, 11, 409-431.

27. Oesterle, H. Foraminiferen der Typlokalitat der Birmenstorfer-Schichten, unterer Malm. Ecl. Geol. Helv. 1968, 61, 695-792.

28. Gradstein, F.M. New and emended species of Jurassic planktonic foraminifera. Swiss J. Palaeontol. 2017, 136, 161-185. [CrossRef]

29. Grigelis, A.A. Globigerina oxfordiana sp. nov. an occurrence of Globigerina in the Upper Jurassic strata of Lithuania. Nauschny Dokl. Vyss. Shkolygeologo-Geogr. Nauk. 1958, 3, 109-111. (In Russian)

30. Birkenmajer, K. Jurassic and Cretaceous lithostratigraphic units of the Pieniny Klippen Belt, Carpathians, Poland. Studia Geol. Pol. 1977, 45, 1-158.

31. Birkenmajer, K. Stages of structural evolution of the Pieniny Klippen Belt, Carpathians. Studia Geol. Pol. 1986, 88, 7-32.

32. Wierzbowski, A.; Jaworska, M.; Krobicki, M. Jurassic (Upper Bajocian-lowermost Oxfordian) ammonitico roso facies in the Pieniny Klippen Belt, Carpathians, Poland: Its fauna, age, microfacies and sedimentary environment. Studia Geologica Polonica $1999,115,7-74$ 
33. Gradstein, F.M. Paleoecology and Stratigraphy of Jurassic Abyssal Foraminifera in the Blake-Bahama Basin, Deep Sea Drilling Project Site 534. In Initial Reports of the Deep Sea Drilling Project; U.S. Government Publishing Office: Washington, DC, USA, 1983; 76, pp. 537-559.

34. Luterbacher, H. Foraminifera from the Lower Cretaceous and Upper Jurassic of the Northwestern Atlantic Ocean. In Initial Reports of the Deep Sea Drilling Project; U.S. Government Publishing Office: Washington, DC, USA, 1972; Volume 11, pp. 561-591.

35. Agterberg, F.P.; Gradstein, F.M.; Nazli, K. Correlation of Jurassic microfossil abundance data from Tojeira sections, Portugal. Geol. Soc. Can. Spec. Pap. 1989, 89, 467-482. [CrossRef]

36. Turner, H.E.; Gradstein, F.M.; Gale, S.A. Bio-chemostratigraphy of the Tojeira Formation (Kimmeridgian), Montejunto, Portugal. Swiss J. Palaeontol. 2017, 136, 297-299. [CrossRef]

37. Görög, Á.; Wernli, R. Protoglobigerinids of the early Kimmeridgian of the Jura mountains (France). J. Foraminifer. Res. 2013, 43, 280-290. [CrossRef]

38. Ascoli, P.; Poag, C.W.; Remane, J. Microfossil zonation across the Jurassic-Cretaceous boundary on the Atlantic margin of North America. Geol. Soc. Can. Spec. Pap. 1984, 27, 31-48.

39. Williamson, M.A.; Stam, B. Jurassic/Cretaceous Epistominidae from Canada and Europe. Micropaleontology 1988, $34,136$. [CrossRef]

40. Görög, A.; Wernli, R. A rare protoglobigerinid association (Foraminifera) from the Tithonian of Gerecse Mts, Hungary. Hantkeniana 2004, 4, 37-45.

41. Gorbachik, T.N.; Poroshina, L.A. New Berriasian planktonic foraminifera from Azerbaydzhan. Transl. Russ. Paleontol. J. 1979, 3, 283-289.

42. Nikishin, A.M.; Wannier, M.; Alekseev, A.S.; Almendinger, O.A.; Fokin, P.A.; Gabdullin, R.R.; Khudoley, A.K.; Kopaevich, L.F.; Mityukov, A.V.; Petrov, E.I.; et al. Mesozoic to recent geological history of southern Crimea and the Eastern Black Sea region. Geol. Soc. Lond. Spéc. Publ. 2017, 428, 241-264. [CrossRef]

43. Arkad'ev, V.V.; Bogdanova, T.N.; Lobacheva, S.V. New data on Berriasian biostratigraphy in the Tonas River Basin (Crimean Mountains). In Cretaceous System of Russia: Problems of Stratigraphy and Paleogeography 111-St; Arkad'ev, V.V., Prozorovskii, V.A., Eds.; NIIZK SpbGU: Petersburg, Russia, 2005. (In Russian)

44. Gradstein, F.; Waskowska, A.; Kopaevich, L.; Watkins, D.K.; Friis, H.; Panera, J.P. Berriasian planktonic foraminifera and calcareous nannofossils from Crimea Mountains, with reference to microfossil evolution. Swiss J. Palaeontol. 2018, 138, 213-236. [CrossRef]

45. Ascoli, P. Foraminiferal and ostracod biostratigraphy of the Mesozoic-Cenozoic, Scotian Shelf, Atlantic Canada. Maritime Sediments 1976, 1, 653-771.

46. Wernli, R.; Ascoli, P.; Williams, G.L. Favusella hoterivica (Subbotina) from the Berriasian and Valanginian of offshore eastern Canada. Rev. De Paleobiol. 1995, 14, 379-398.

47. Barss, M.S.; Bujak, J.P.; Williams, G.L. Palynological zonation and correlation of sixty-seven wells, eastern Canada. Palynol. Zonation Correl. Sixty-Seven Wellseastern Can. 1979, 78-24, 117. [CrossRef]

48. Omaña, L.; Gonzales-Arreola, C.; Nunez-Useche, F. The Berriasian-Valanginian boundary interval based on calpionellids from the Taraises Formation, Cuencame de Ceniceros, Durango, NW Mexico: Biostratigraphic, paleoecologic and paleobiogeographic significance. J. South. Am. Earth Sci. 2017, 80, 589-600. [CrossRef]

49. Poisson, A. Recherches Geologiques dans les Taurides Occidcntales. Ph.D. Thesis, Université d'Orsay, Paris, France, 1977; 795p.

50. Petrizzo, M.R.; Wade, B.S.; Gradstein, F.M. Planktonic foraminifera. In The Geologic Time Scale 2020 Volume 1; Gradstein, F.M., Ogg, J.G., Schmitz, M.D., Ogg, G.M., Eds.; Elsevier: Amsterdam, The Netherlands, 2020.

51. Wernli, R.; Görög, A. Protoglobigérines et Oberhauserellidae (Foraminifères) du Bajocien-Bathonien du Jura méridional, France. Rev. De Micropaléontologie 2007, 50, 185-205. [CrossRef]

52. Gorbachik, T.N. Globuligerina oxfordiana (Grigelis)-A typical species of the genus Globuligerina in electron microscope. Akad. Nauk. Sssr 1983, 26, 48-51. 